\title{
A REVISION OF THE \\ NEW WORLD GENUS CHROMOCRYPTUS (HYMENOPTERA: ICHNEUMONIDAE).
}

\author{
By Charles C. Porter ${ }^{1}$ and Thomas J. O’Neill \\ Department of Biological Sciences, \\ Fordham University, \\ Bronx, NY 10458
}

\section{INTRODUCTION}

Taxonomy

Chromocryptus is a strictly New World representative of the cosmopolitan ichneumonid subtribe Ischnina (Gelinae: Mesostenini), as defined by Townes (1969: 158-9). It may be distinguished from other Nearctic and Neotropic ischnines by the following concert of features: (1). Black, red, and white (sometimes mostly red); (2). Wings hyaline to moderately infumate; (3). Clypeus pyramidally raised, often nasute; (4). Mesoscutum largely with coarse punctures or puncto-reticulation and with notauli only faintly defined (fine but well impressed in some males); (5). Hind coxa with a strong subvertical groove externo-ventrally near base; (6). Discocubitus gently arched to weakly angled, sometimes with a vestigial ramellus; (7). Axillus very close to hind margin of hind wing; (8). Propodeal spiracle 1.3-3.0 as long as wide; (9). Propodeal cristae large and well projecting, obtusely cuneate to subligulate, never spiniform; (10). Base of 1st gastric tergite with a lateral expansion that is low and rounded or sometimes prominently subtriangular; (11). Female gaster short and stout, short-fusiform to almost ovoid; (12). Second gastric tergite with abundant large punctures that usually are subadjacent or denser; its setae short but mostly approaching the length of their interspaces; (13). Ovipositor slender to robust, straight, compressed; its sheathed portion $0.35-0.45$ as long as fore wing. The foregoing diagnosis easily distinguishes Chromocryptus from its

'Research Associate, Florida State Collection of Arthropods, Florida Department of Agriculture and Consumer Services, P. O. Box 1269, Gainesville, F1 32602.

Manuscript received by the editor May 15, 1985. 
North and Middle American relatives, but must be used with care in considering the complex South American fauna. A complete description is furnished later in this study antecedent to the key for Chromocryptus species.

My concept of Chromocryptus agrees with Townes earlier interpretations (1962: 256-7). Some recent authors (Porter 1967: 206-11, Townes 1966: 68) have regarded Chromocryptus as a species group within the immense, almost exclusively South American genus Trachysphyrus Haliday. In 1969 (179-81), Townes restricted Chromocryptus to those "Trachysphyrus" in which the axillus vein runs close to the posterior margin of the hind wing. This arrangement still leaves under Chromocryptus a heterogeneous and perhaps polyphyletic complex of more than 45 species. I thus prefer to return to Townes' 1962 perception of the genus and to regard it as comprising only those species intimately related to the North American $C$. planosae. This viewpoint has been strengthened by discovery of 5 previously unknown Argentine and Peruvian taxa that agree in most points with C. planosae.

\section{RELATIONSHIPS}

Chromocryptus probably is related to at least some of the stocks formerly included under Trachysphyrus (Porter 1967). It may be particularly close to the central Argentine Xiphidium group of Trachysphyrus (Porter 1967: 211-15). In both groups the 2nd gastric tergite has large, dense punctures and the base of the petiole shows an at least moderately well developed lateral flange or blunt tooth. The Xiphidium group differs from Chromocryptus in having the axillus vein far from the hind margin of its wing. Species of the Xiphidium group thus belong to Trachysphyrus, as most recently defined (Townes 1969: 181-3). However, displacement anteriad of the axillus vein (a derived feature in ichneumonids) probably has occurred independently several times within various evolutionary lines associated with Trachysphyrus. Further studies, consequently, might allow expansion of Chromocryptus to include those species currently grouped with Trachysphyrus xiphidium.

\section{Geographic Distribution and Ecology}

Chromocryptus ranges throughout most of the New World from the northeastern United States and California to México, Perú, 
Argentina, and Brasil. It has not been recorded from the Neantarctic Biotic Province of South America (Chile and adjoining southwest Argentina) nor from any of the West Indian islands.

Of the known species, 6 occur in northern Argentina and/or Brasil, 1 is reported from the Peruvian Coastal Desert, 1 from México and the southern United States, 1 from Florida, 1 from the northeastern United States, and 1 from central California. Habitats occupied by Chromocryptus include Temperate Deciduous Forest (C. planosae), Floridian Subtropical Evergreen Forest (C. weemsi and eastern populations of C. mesorufus), Tamaulipan Subtropical Thorn Scrub (western populations of $C$. mesorufus), Chaco-like Tropical Thorn Scrub on the north Peruvian coast (C. teres), the northwest Argentine Andean ecotone between Subtropical Cloud Forest, highland Chaco, and Montane Temperate Forests (C. alvaradoi and some populations of $C$. tomsici), the northwest Argentine Andean Desert or Prepuna (some populations of C. tomsici), the north-central Argentine Dry Chaco (C. prosopis, C. golbachi), and very wet subtropical to tropical forests in the south Brasilian biotic zone (C. huebrichi).

Wherever it occurs, Chromocryptus almost always seems extraordinarily scarce. Specimens which I have observed usually were crawling or flying within the shelter of spiny shrubs. I suspect they may be common in such microhabitats, from which they rarely emerge to enter Malaise Traps and in which it is difficult for the collector to detect and net them.

\section{Hosts}

Chromocryptus have been reared most often from tough lepidopterous cocoons attached to bark. Lasiocampidae are the usual hosts, with $C$. planosae recorded from Epicnaptera and Tolype in the eastern United States and C. huebrichi cited from Titya near Buenos Aires, Argentina. There is also 1 rearing for $C$. planosae from the arctiid genus Halisidota.

Parasitism by Chromocryptus is gregarious, with up to 22 specimens emerging from a single host cocoon (Porter 1967: 33-4). This habit also has been recorded for the Chilean Trachysphyrus horsti and the Argentine T. chacorum, but has not been noted among such commonly reared Holarctic "trachysphyroid" genera as Itamoplex and Buathra. Pratt (1945: 551) believes C. planosae to be polyembryonic. 


\section{INFRAGENERIC AFFINITIES}

Chromocryptus forms a compact genus in which establishment of subgenera or species groups seems as yet unnecessary. Little has been discovered about the ancestral or derived nature of the states of features used to separate these species, so that phylogenetic analysis within Chromocryptus would be premature.

Nonetheless, some idea of relationships within the genus may be derived from the following hierarchically indented schema:

I. Ovipositor stout, its tip not sagittate; fore tibia swollen; clypeus approximately symmetric, convex to bluntly pyramidal .......................... C. alvaradoi.

II. Ovipositor slender and delicate, its tip sagittate; fore tibia not inflated; clypeus asymmetrically and nasutely pyramidal.

1. Mesopleuron with conspicuous, long, rather regular wrinkles that radiate extensively from speculum; mesoscutum with some smooth areas between puncto-reticulation on both median and lateral lobes ...................

C. poecilma, C. teres.

2. Mesopleuron without or with only short wrinkles radiating from speculum; mesoscutum usually without smooth areas among the coarse sculpture ......... planosae, C. mesorufus, C. weemsi, C. vandykei, C. huebrichi, C. prosopis, C. golbachi, and C. tomsici.

Plausibly, Chromocryptus alvaradoi diverged early from the Chromocryptus evolutional line. Specializations, possibly associated with parasitism of small hosts and with a newly acquired polyembryonic life style, then led to the origin of a cluster of smaller species with more delicate ovipositors. More recently, this latter category has subdivided into the weakly differentiated Poecilma and Planosae complexes.

\section{Collections ExAmined}

Listed below in alphabetic order are the collections which furnished material for this research and/or in which type specimens are to be deposited. I refer to institutional collections by the name of the city in which they are located and to individual collections by the surname of their owner. 
CAMBRIDGE. Museum of Comparative Zoology, Harvard University, Cambridge, MASS 02138.

COllege Station. Department of Entomology, Texas A \& M University, College Station, TX 77843.

GAINESviLLE. Florida State Collection of Arthropods, Bureau of Entomology, Division of Plant Industry, Florida Department of Agriculture and Consumer Services, P. O. Box 1269, 1911 SW 34th Street, Gainesville Fl 32602.

LAWRENCE. Department of Entomology, Snow Entomological Museum, The University of Kansas, Lawrence, KS 66045.

otTAWA. Canadian National Collection, Biosystematics Research Institute, Agriculture Canada, Ottawa K1A 06C, CANADA. PORTER. Collection of Charles C. Porter, 301 North 39th Street, McAllen, TX 78501.

TOWNES. American Entomological Institute, c/o Dr. Virendra Gupta, Bureau of Entomology, Division of Plant Industry, Florida Department of Agriculture and Consumer Services, Gainesville, Fl 32602.

\section{Genus CHROMOCRYPTUS}

Chromocryptus Ashmead, 1900. Proc. U.S. Natl. Mus. 23: 41. Type: (Chromocryptus albopictus Ashmead) = planosae (Fitch).

Mesostenimorpha Viereck, 1913. Proc. U.S. Natl. Mus. 44: 566. Type: (Cryptus nebraskensis Ashmead) = planosae (Fitch).

Fore wing 3.4-9.1 mm long. Coloration usually black, red, and white (occasionally mostly red) with hyaline to moderately dusky wings. Flagellum moderately long and slender, a little flattened below toward apex in female, in male with some segments bearing sharp and linear longitudinal tyloids, its 1st segment 3.7-6.2 as long as deep at apex. Mandible rather short and broad with lower tooth often a little shorter than the upper. Clypeus in profile asymmetrically to symmetrically pyramidal, often nasute; its apical margin edentate. Occipital carina sharp and narrow, usually sinuate laterally, reaching the weakly to moderately raised hypostomal carina below. Malar space $0.50-1.0$ as long as basal width of mandible. Pronotum a little swollen on dorsal margin and with the submarginal groove vague or absent to shallowly defined; epomia sharp 
in scrobe and sometimes a little prolonged dorsad, where it occasionally terminates in a weak swelling. Mesoscutum with notaulus weak (sometimes rather strong in male) but traceable 0.5 or more the length of mesoscutum; surface at least in part coarsely and densely punctate, reticulo-punctate, or reticulately wrinkled. Mesopleuron with speculum largely smooth and shining or sometimes much invaded by coarse wrinkling; its surface otherwise wrinkled and/or puncto-reticulate; no ridge on prepectus below. Fore tibia scarcely to palpably inflated. Hind coxa with a sharp and strong subvertical groove externo-ventrally near base. Wing venation: radial cell 3.3-4.4 as long as wide; areolet large, moderately broad to rather high and narrow, its intercubiti slightly to definitely convergent above; 2 nd recurrent vertical or reclivous, straight or slightly outcurved dorsad; discocubitus gently arched to broadly angled, sometimes with a vestigial ramellus; mediella beyond base usually weakly arched but fairly strongly arched in some males; axillus very close to and paralleling hind margin of wing. Propodeum: spiracle 1.3-3.0 as long as wide; profile short and high; basal trans-carina traceable and often sharp throughout; apical trans-carina irregular but traceable between cristae, sometimes strong; cristae large and obtusely cuneate to subligulate, often strongly projecting; median longitudinal carinae often traceable but weak in female but stronger in males, where they often define both an areola and a median apical area. First gastric tergite: petiole at base with a low and rounded to often prominent and subtriangular lamella; postpetiole usually strongly expanded, in females $1.7-2.3$ as wide apically as long from spiracle to apex and in males 1.2-1.9 as wide; surface of postpetiole at most with vague dorsal carinae and with a few to very many medium sized to large and frequently conspicuous punctures; ventral longitudinal carina defined throughout. Second gastric tergite with abundant, medium sized to large, shallow to (often) sharp punctures that are mostly subadjacent to (often) adjacent; its setae abundant but short and often (but not always) mostly equal to the length of their interspaces. Ovipositor: sheathed portion $0.34-0.45$ as long as fore wing; straight, slender to robust, compressed; nodus distinct to obsolete; notch vague to rather large but shallow; dorsal valve with a steep to very gentle taper between notch and apex; tip 0.14-0.21 as high at notch as long from notch to apex; ventral valve on tip with ridges weak and inclivously oblique to sharp and almost vertical. 


\section{Key to THE SPeCIES OF CHROMOCRYPTUS}

FEMALES

(Female of C. golbachi unknown.)

1. South American species (Perú, Argentina, Brasil) .........5

$1^{\prime}$. Mexican and North American species ...............

2. Propodeum and mesopleuron largely red; 2 nd and 3rd gastric tergites with apical white bands obsolete or absent .......3

2 '. Propodeum and mesopleuron black and white, without conspicuous red areas; 2 nd and 3rd gastric tergites with prominent white apical bands .....................4

3. Ground color of head, pronotum, and mesoscutum black; hind face of propodeum with a pair of white bars that reach from cristae to its apical margin; gastric tergites 4-7 with white apical bands and otherwise mostly blackish; punctures on upper 0.3 of mesopleuron mostly adjacent to subadjacent; sheathed portion of ovipositor 0.30 as long as fore wing.... ..... 1. C. planosae (Fitch)

3'. Ground color of head, pronotum, and mesoscutum red; propodeum red with only a trace of whitish on cristae and area immediately apicad; gastric tergites 4-7 red with white apical bands on 5-7; punctures on upper 0.3 of mesopleuron mostly reticulately confluent; ovipositor 0.40 as long as fore wing 2. C. weemsi (Porter)

4. Second and succeeding gastric tergites black with apical band; broad white stripe in anterior 0.6 of sternaulus; hind femur and tibia dusky on apex; hind tarsus partly white .........

3. C. mesorufus Cushman

4'. Second and succeeding gastric tergites red with a white apical band; only a trace of white in sternaulus; hind femur and tibia not dusky on apex; no white on hind tarsus..........

4. C. vandykei Townes

5. No white on propodeum; fore wing palpably darkened toward apex, 8.6-9.1 $\mathrm{mm}$ long; speculum invaded by coarse wrinkles; fore tibia stout and inflated; propodeal spiracle 2.3-3.0 as long as wide; ovipositor robust, its notch and nodus obsolete, its profile on tip weakly tapering and not sagittate, its ventral valve on tip with strong, almost vertical ridges ..... 
5'. Hind face of propodeum with a pair of conspicuous white lateral bars between cristae and apical margin; fore wing nearly hyaline, 3.4-6.7 mm long; speculum largely smooth; fore tibia slender and scarcely inflated; propodeal spiracle 1.3-2.1 as long as wide; ovipositor slender and delicate, its notch and nodus usually detectable, its profile on tip more strongly tapering and sagittate, its ventral valve on tip with delicate, inclivously oblique ridges...................6

6. Mesoscutum not uniformly reticulo-punctate; mesopleuron with long wrinkles that radiate from speculum; gaster red with variably developed white apical bands on all but 3 rd tergite .......................................7

6'. Mesoscutum throughout coarsely reticulo-punctate; mesopleuron with fine reticulo-punctation and wrinkling but without long rugae that radiate extensively from speculum; gaster dull to bright red, sometimes with considerable blackish suffusion, and often with white absent or obsolete on apices of 1 st and/or 2nd tergites ...................... 8

7. Face mostly white; large white blotch in upper hind corner of mesopleuron; postpetiole with scattered large and strong punctures that become subadjacent laterad and apicad; 2nd gastric tergite with mostly subadjacent to adjacent large and sharp punctures...............6. C. poecilma (Porter)

$7^{\prime}$. No white on face or in upper hind corner of mesopleuron; postpetiole with only a few small to medium sized and scattered punctures; 2nd gastric tergite with abundant medium sized and shallow punctures that are separated by $1-3 \times$ their diameters or more............... C. teres $n$. sp.

8. Pair of white stripes on mesoscutum; large anterio-median white blotch on mesopleuron; large, ellipsoid white area on apical 0.5 of lower metapleuron; no white on 1st and 2nd gastric tergites ................ 8. C. huebrichi (Brèthes)

$8^{\prime}$. No white on mesoscutum and on mesopleural disc; lower metapleuron at most with a tiny white area at apex; 1st (and sometimes 2nd) gastric tergite with a white apical band....9

9. White flagellar band begins on 6th segment; basal 0.3-0.6 of scutellum white; white apical bands on both 1st and 2nd gastric tergites; 4 th gastric tergite with its broad white apical 
band abruptly truncate laterally; areolet nearly parallelsided, the intercubiti scarcely convergent above; propodeal cristae asymmetric, cuneo-ligulate; 2 nd gastric tergite with its large punctures mostly subadjacent and surface between punctures with only faint micro-aciculation .............

9. C. prosopis n. sp.

9'. White flagellar band begins on 7th segment; basal 0.3 of scutellum white; no white apical band on 2nd gastric tergite; white apical band of 4th gastric tergite nearly complete, not abruptly cut off laterally; areolet not parallel-sided, the intercubiti definitely convergent above; propodeal cristae symmetrically short-ligulate; 2 nd gastric tergite with its large punctures in great part practically adjacent and surface between punctures with palpable micro-aciculation........ 10. C. tomsici n. sp.

MALES

(Males of C. alvaradoi, C. mesorufus, C. poecilma, C. teres, and C. vandykei unknown).

1. South American species (Argentina, Brasil) ............. 3

$1^{\prime}$. North American species .......................

2. Ground color of head, pronotum, and mesoscutum black; hind face of propodeum with a pair of white blotches from cristae to hind margin; gastric tergites 4-7 with white apical bands and otherwise mostly blackish; punctures on upper 0.3 of mesopleuron at least partly discrete..$\ldots \ldots \ldots \ldots \ldots$. 1. C. planosae (Fitch)

$2^{\prime}$. Ground color of head, pronotum, and mesoscutum red; propodeum red with only a trace of white on cristae and area immediately apicad; gastric tergites 4-7 uniformly red; punctures on upper 0.3 of mesopleuron reticulately confluent...

2. C. weemsi (Porter).

3. Pair of white stripes on mesoscutum; white blotch on clasper; no white on 1st and 2nd gastric tergites, the 4th and following tergites blackish with white apical bands; notauli faint, extending $0.5-0.6$ the length of mesoscutum............

8. C. huebrichi (Brèthes) 
3'. No white stripes on mesoscutum (occasionally a median white blotch); no white on clasper; ground color of gaster usually in large part red, 1st gastric tergite with at least a vague white apical band, 2nd tergite with or without a white band, 3rd tergite with or without a white band, 4th and 5th tergites often with an apical white band; notauli fine but impressed, reaching $0.7-0.8$ the length of mesoscutum ...........4

4. Large white spot on mesoscutum between ends of notauli; postscutellum mostly white; gaster bright red with broad white apical bands on tergites 1-5; mesopleural disc on upper 0.5 with rather fine and longitudinally biased variably reticulate wrinkling and on lower 0.5 uniformly puncto-reticulate; postpetiole 1.8-1.9 as wide apically as long from spiracle to apex .................... 11. C. golbachi n. sp.

4'. No white on mesoscutum; no white on postscutellum; gaster duller red with white bands not as described above; mesopleural disc uniformly with rather fine and granular punctoreticulation; postpetiole $1.2-1.7$ as wide apically as long from spiracle to apex ..........................

5. Mesopleuron extensively white; gaster bright to dull red with some dusky staining, with a broad white apical band on tergites 1 and 2, a narrow white band on tergite 3 , a broad but laterally aborted white band on 4 , and no white on 5 th and following tergites; malar space $0.53-0.66$ as long as basal width of mandible; postpetiole 1.6 as wide apically as long from spiracle to apex; large punctures on postpetiole uniformly subadjacent to reticulately confluent ............

9. C. prosopis n. sp.

5'. Mesopleuron with only a small white area in lower hind corner; gaster red with some dusky suffusion, with white vaguely on apex of 1st tergite, no white apical bands on tergites 2 and 3, with a broad but laterally aborted band on tergite 4 , and with white apical bands on 5th and following tergites; malar space 0.80 as long as basal width of mandible; postpetiole 1.2 as wide apically as long from spiracle to apex; large punctures on postpetiole irregularly spaced, not uniformly subadjacent or denser, sometimes mostly sparse $\ldots \ldots \ldots \ldots \ldots \ldots \ldots$. 


\section{Chromocryptus planosae (Fitch)}

(Figs. 1, 2, 6).

Phygadeuon planosae Fitch, 1856. Trans. New York State Agr. Soc. 15: 501. Holotype ?: New York (Washington).

Cryptus nebraskensis Ashmead, 1890. Proc. U.S. Natl. Mus. 12: 412. Type $\%:$ West Point, Nebr. (Washington).

Chromocryptus albopictus Ashmead, 1900. Proc. U.S. Natl. Mus. 23: 41. Type + :

Urbana, Ill. (Washington).

Agrothereutes (Itamoplex) cressonii Viereck, 1917. Bull. Connecticut Geol. Natl.

Hist. Surv. 22: 1332. Type $q$ : Connecticut (Philadelphia).

Chromocryptus planosae planosae Townes, 1962. Bull. U.S. Natl. Mus. 216(3): 257. Trachysphyrus planosae Porter, 1967. Mem. Amer. Ent. Inst. 10: 207.

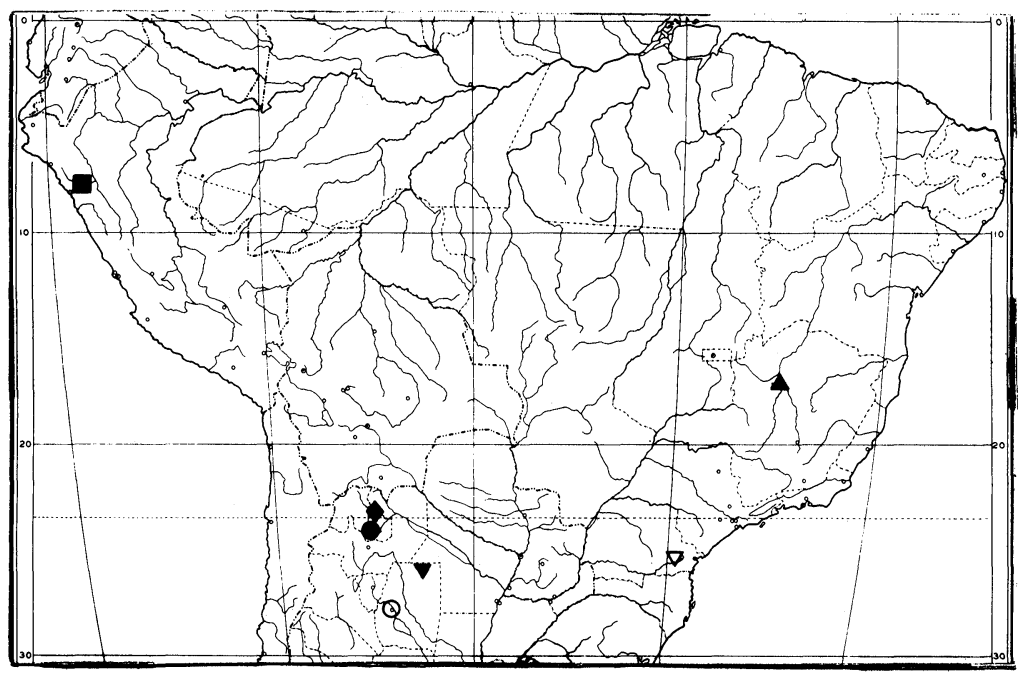

1. C. alvaradoi (Jujuy Province, Argentina)

2. C. poecilma (Minas Gerais, Brasil)

3. C. teres (Simbal near Trujillo, Perú)

4. C. huebrichi (Curitiba, Brasil...also south to eastern Argentina) ...... $\nabla$

5. C. prosopis (Santiago del Estero, Argentina) ..................

6. C. tomsici (Jujuy Province, Argentina) .....................

7. C. golbachi (Santiago del Estero Province, Argentina)

Fig. 1. Distribution map for Chromocryptus in tropical and subtropical South America. 
Townes' revisionary study of this taxon (1962: 256-8) summarizes the characters that separate $C$. planosae from other North and Middle American Chromocryptus. It defines the species biogeographically as a member of the Temperate Deciduous Forest Biome in eastern North America from Massachusetts south to Pennsylvania west to Michigan, Indiana, Illinois, and Nebraska. It also cites numerous host records for C. planosae as a "gregarious parasite" in pupae of the bombycoid genera Tolype and Epicnaptera (Lasiocampidae) and one rearing from the noctuoid Halisidota (Arctiidae).

No additional data have accumulated on $C$. planosae, since the publication of Townes' monograph.

\section{Chromocryptus weemsi (Porter)}

(Figs. 1, 5)

Trachysphyrus weemsi Porter, 1974. Fla. Ent. 57: 331. Holotype \&: Sarasota, Florida (Gainesville).

Chromocryptus weemsi Carlson, 1979. Catalog of Hymenoptera in America North of Mexico 1: 458.

This species is known from 2 females and 1 male collected at Sarasota, Florida in McPhail and Steiner Traps during late winter and early spring (24 February to 14 April). In 1974 (331-5), I described Chromocryptus weemsi in relation to its northeast American relative, $C$. planosae. The species are closely allied but seem distinct on the basis of chromatic, sculptural, and proportional features, as summarized in the foregoing key.

\section{Chromocryptus mesorufus Cushman}

(Figs. 1, 7)

Chromocryptus mesorufus Cushman, 1930. Proc. U.S. Natl. Mus. 76: 2. Holotype Cuernavaca, México (Washington).

Chromocryptus planosae mesorufus Townes, 1962. Bull. U.S. Natl. Mus. 216(3): 259. Trachysphyrus mesorufus Porter, 1977. Psyche 84(1): 33-5.

Chromocryptus mesorufus shows great affinity to the eastern North American C. weemsi and C. planosae, as well as to C. huebrichi of southern Brasil and northeast Argentina. It occurs in México (Cuernavaca), the Lower Río Grande Valley of south Texas (McAllen), and recently has been reported at Miami, Florida in a blacklight trap (Carlson 1979: 457). The essential sympatry of $C$. 

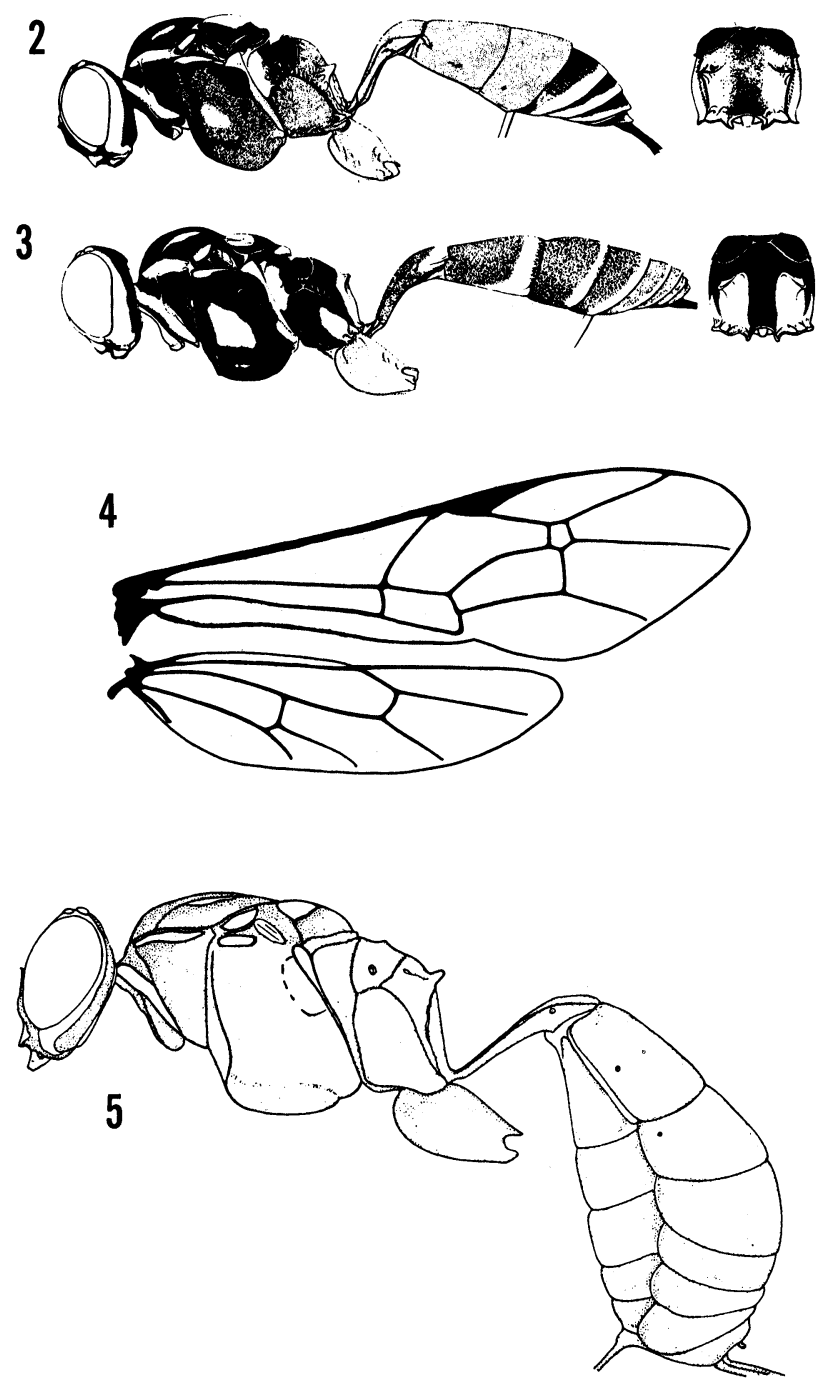

Fig. 2. Chromocryptus planosae, ㅇ. Body in lateral view and propodeum in dorsal view, showing habitus and color pattern. (From Townes 1962: 554). Fig. 3. Chromocryptus vandykei, . . Body in lateral view and propodeum in dorsal view, showing habitus and color pattern. (From Townes 1962: 554). Fig. 4. Chromocryptus huebrichi, . . Wings. (From Porter 1967: Fig. 71). Fig. 5. Chromocryptus weemsi, . Holotype. Lateral view of body showing habitus and color pattern. (From Porter 1974: 332). 
mesorufus and $C$. weemsi in southern Florida seems to confirm the specific distinctness of these close congeners.

A full description of $C$. mesorufus appears in my survey of mesostenine Ichneumonidae in the Lower Río Grande Valley (Porter 1977: 33-5). My Texas specimen was collected on 2 April 1975 at the McAllen Botanical Garden, where I swept it from thorny bushes at a site "dominated by Prosopis juliflora" with Condalia obovata, Celtis pallida, Ehretia anaqua, and Baccharis neglecta in the small tree and shrub stratum.

\section{Chromocryptus vandykei Townes}

(Fig. 3)

Chromocryptus planosae vandykei Townes, 1962. Bull. U.S. Natl. Mus. 216(3): 258. Holotype \%: "Havilah", Fresno, California (San Francisco).

Chromocryptus vandykei Carlson, 1979. Catalog of Hymenoptera in America north of Mexico 1: 458.

This is the only Chromocryptus of which I have not personally examined material. It remains known only from the unique holotype collected at Havilah, Fresno, County, California on 16 May 1930 by E. C. Van Dyke. It may be identified by reference to the foregoing key and to Townes' original treatment [1962 (3): 258-9].

\section{Chromocryptus alvaradoi Porter, new species}

(Figs. 1, 13)

Female. Color: antenna black with some brown staining, especially below toward apex, and with a white band above on flagellomeres 6-9; head and mesosoma black with white markings as follows: orbital ring rather broadly, except for a brief interruption at bottom of eye and sometimes another short break above at level of front ocellus; transverse blotch on clypeus; large blotch on basal 0.5 of mandible; anterior margin of pronotum broadly over about median 0.8; white band on humeral margin of pronotum, which apicad becomes narrower, sometimes irregular, and sometimes suffused with brown; most of tegula; most of subalarum; about basal 0.4-0.3 of scutellum; and sometimes a spot in lower hind corner of mesopleuron; gastric tergites 1-3 varying from mostly red with much blackish staining laterad on 2 and 3 to mostly black with irregular reddish suffusion, the 2 nd tergite sometimes with a small 
white area in its hind corner, and the 3rd tergite with a regular and only sublaterally interrupted or irregular and much fragmented white apical band; tergites 4-7 black with white apical bands that are narrowest dorsad and which become considerably broadened laterally; and tergite 8 black with dorsally interrupted apical white band; fore coxa varying from reddish white with much black staining to black with reduced red suffusion and with a large ventrolateral white blotch as well as a somewhat smaller dorso-lateral white area; mid coxa varying from red with a little dusky to black with some reddish staining and with a large latero-ventral white blotch as well as with smaller and more irregular latero-basal and apico-dorsal whitish areas; hind coxa red, with some black apicad or sometimes mostly black with a large dorso-lateral white blotch at base and with only a little reddish staining (particularly around the white blotch); fore and mid trochanters black with pale brown to whitish narrowly on apex and sometimes with a white spot ventrally on fore trochanter; fore and mid trochantelli shining brown, becoming dusky basad; hind trochanter black with some brown staining and narrowly whitish on apex; hind trochantellus mostly shining brown; femora and tibiae a little dully pale orange; hind femur also blackish on apex and hind tibia likewise with blackish both near base and apex; fore and mid tarsi brownish with considerable dusky staining beyond 1st segment; hind tarsus sometimes wholly black or sometimes with segments 3 and 4 white above on all but apex; wings subhyaline with moderately prominent dusky staining that is most evident on apical $0.2-0.3$ of fore wing.

Length of fore wing: 8.4-9.1 mm. Flagellum: moderately long and slender, becoming slightly stouter and a little flattened below on about apical 0.3 ; last flagellomere apically truncate; 1st flagellomere 5.6-6.2 as long as deep at apex. Clypeus: in profile strongly highconvex to bluntly pyramidal, only a little asymmetric (basal face convex and approximately as long as the weakly concave apical face); apical margin practically truncate. Malar space: $0.73-0.80$ as long as basal width of mandible. Temple: $0.39-0.44$ as long as eye in dorsal view; strongly and directly receding. Fore tibia: stout and considerably inflated. Pronotum: with a more or less well defined and rather broad and shallow dorsal submarginal groove that becomes narrower and weaker behind. Mesoscutum: notauli weak and shallow, traceable 0.5 the length of mesoscutum; surface 
moderately shining with coarse reticulate wrinkling over a broad area along notauli, on periphery of lateral lobes, and more or less throughout toward apex, but mesad on central and lateral lobes becoming duller and with many moderately large, strong, subadjacent to confluent punctures and definite fine micro-reticulation. Mesopleuron: speculum shining with much coarse wrinkling or sometimes also partly smooth and shining; surface otherwise with coarse reticulate wrinkling. Wing venation: radial cell 4.0-4.4 as long as wide; areolet large, intercubiti moderately to somewhat strongly convergent above, 2nd abscissa of radius $0.7-0.8$ as long as 1st intercubitus; 2nd recurrent weakly inclivous, almost straight; discocubitus at most weakly angled, with or without a stump of a ramellus; nervulus antefurcal; upper part of nervellus 1.8-2.0 as long as lower; axillus close to hind margin of wing. Propodeum: short and high, with the basal face gently and convexly sloping rearward and the approximately equal apical face discrete and almost vertically declivous; spiracle $2.3-3.0$ as long as wide; basal trans-carina sharp throughout, strongest medially; apical transcarina weak and irregular, best defined medially; cristae short ligulate, large, stout, conspicuously projecting; median longitudinal carinae irregularly detectable, defining a more or less sharply hexagonal and wider than long areola and very faintly demarking a median apical area; surface coarsely reticulately wrinkled, except with definitely finer wrinkling and some intercalated punctures basad of basal trans-carina. First gastric tergite: petiole moderately slender and with a broad, rounded-off subtriangular lateral expansion at base; postpetiole strongly widened, $1.8-2.1$ as wide apically as long from spiracle to apex; surface of postpetiole broadly smooth and shining, without dorsal carinae and with a little microshagreening (sometimes extensive shagreening) centrally and laterally, and on apical 0.3 with many large, strong, subadjacent or a little sparser to adjacent or restrictedly confluent punctures, as well as with some widely scattered large punctures elsewhere. Second gastric tergite: smooth and shining with only faint micro-shagreening and with abundant large, sharp, mostly briefly subadjacent to adjacent or reticulately confluent punctures that emit short, scarcely overlapping setae. Gaster: rather short and stout fusiform; 3rd tergite with punctures nearly as strong and dense as those on 2 nd, but the following tergites with considerably weaker and sparser punc- 
tures. Ovipositor: sheathed portion $0.39-0.41$ as long as fore wing; straight, stout, markedly compressed; nodus very slightly suggested and with at most a faint trace of a notch; dorsal valve very gradually tapering from nodal area to near apex and then becoming slightly convex in profile on apex; ventral valve on tip with strong and nearly vertical ridges; tip 0.20 as high at nodal area as long from nodal area to apex.

MaLE. Unknown.

Type Material. Holotype \&: ARGENTINA, Jujuy Province, Posta de Lozano, 27-30-XI-1967, C. Porter, E. Willink. Paratype: 1 , same locality as holotype, 6-XII-1967, C. Porter. Holotype in Florida State Collection of Arthropods; paratype in Collection of Charles C. Porter.

Relationships. Chromocryptus alvaradoi deviates markedly from other species of its genus. It shows many chromatic and structural differences from all South and North American congeners. Some of these diagnostic features include the infuscate wings, absence of white markings on the propodeum, greater size, high but not asymmetric clypeus, inflated fore tibia, coarse wrinkling on much of speculum, comparatively long propodeal spiracle, and robust ovipositor with its weakly tapering (instead of sagittiform) tip and vertical ridges on the lower valve.

At Posta de Lozano, this Chromocryptus occurs sympatrically with $C$. tomsici, a much smaller species that is closely related to $C$. huebrichi and C. planosae. The two form show no evidence of intergradation and confirm their specific integrity by adaptive differences (e.g., ovipositor tip structure) which surely bespeak distinct host preferences.

FIELD Notes. The type locality is situate on Argentine National Route 9 in Jujuy Province about $25 \mathrm{~km}$ north of San Salvador de Jujuy and between the villages of Yala and León. Posta de Lozano faces the entrance to the Quebrada de Humahuaca at about $1600 \mathrm{~m}$ altitude. The area supports a singularly diverse vegetation with elements of subtropical wet forest (Erythrina, many epiphytic bromeliads), Alder Forest (Alnus jorullensis), and, in drier exposed sites, with Chaco communities dominated by Serjania-festooned Acacia and Celtis.

SPECIFIC NAME. For Dr. Carlos Alberto Alvarado, the distinguished Argentine Medical Entomologist and propietor of the Posta de Lozano Motel, a hospitable base for enthralling fieldwork. 
6. Chromocryptus poecilma (Porter), new combination

(Fig. 1)

Trachysphyrus poecilma Porter, 1967. Mem. Amer. Ent. Inst. 10: 210-1. Holotype q: Pirapora, Minas Gerais, Brasil (Cambridge).

Female. Color: antenna dull brownish black with a large white blotch below on scape and a white band above on flagellomeres 6 (apically)-12 (basally); head and mesosoma black with profuse white markings as follows: basal 0.6 of mandible; most of clypeus; most of face; very broad orbital band which expands across most of temple behind and fills malar space below; propleuron apically; broad anterior margin of pronotum; broad dorsal margin of pronotum, except on median 0.3; pair of stripes on mesoscutum; all but apex of scutellum; tegula; subalarum; anterior margin of mesopleuron dully; very broad oblique band between prepectus at mid-height and lower hind margin of mesopleuron, from which an ellipsoidal branch reaches forward below along sternaulus almost to prepectal carina; large blotch in upper hind corner of mesopleuron; posterior margin of mesopleuron; upper metapleuron; and all of posterio-lateral area of propodeum from crista to hind margin; gaster pale red with broad, complete white apical bands on tergites 1,2 , and 4 , as well as with narrower and dorsally incomplete white apical bands on tergites 5-7; fore and mid coxae and trochanters white, legs otherwise mostly pale red, with some dusky on fore and mid apical tarsomeres, toward apex of hind tibia, and more distinctly on hind tarsus which also has a white subapical external area on 1st segment and segments 2-4 wholly white; wings hyaline.

Length of fore wing; $5.6 \mathrm{~mm}$. Flagellum: 1 st segment 4.8 as long as deep apically. Malar space: 1.0 as long as basal width of mandible. Temple: 0.30 as long as eye in dorsal view; a little rounded off and strongly receding. Mesoscutum: notauli very weak and shallow, vaguely suggested for about 0.6 the length of mesoscutum; surface rather dully shining with some fine micro-reticulation and with abundant, large, strong, subadjacent to adjacent or confluent punctures that average sparsest on lateral lobes but which also become widely spaced for a short distance on central lobe medially, the surface also with more or less well developed oblique wrinkling along notauli and with some reticulate wrinkling over an extensive central area behind. Mesopleuron: speculum swollen, smooth and 
polished; surface otherwise with fine, mostly regular long wrinkles radiating from speculum and gradually fading into reticulopunctation on anterio-ventral 0.5 of mesopleuron. Propodeum: spiracle 1.5 as long as wide; basal trans-carina medially sharp but lower and somewhat irregular sublaterally; apical trans-carina strong, becoming irregular medially; cristae large, strongly projecting, obtusely cuneate; median apical area rather strongly but irregularly defined; surface coarsely reticulately wrinkled. First gastric tergite: postpetiole 2.0 as wide apically as long from spiracle to apex; surface of postpetiole shining with fine and distinct microreticulation which fades out apically and with scattered large, strong punctures which are most abundant apicad and (especially) laterad, where they average largely subadjacent; setae short and mostly well separated. Second gastric tergite: shining with fine, distinct microreticulation which becomes stronger laterad and also with abundant large, sharp, mostly subadjacent to adjacent punctures emitting short setae that mostly equal or fall short of the length of their interspaces. Ovipositor: tip 0.16 as high at notch as long from notch to apex.

MALE: Unknown.

Discussion. This species is closely related to $C$. teres Porter, but may be distinguished by the characters given in the key. The holotype is the only specimen so far collected.

\section{Chromocryptus teres Porter, new species}

(Figs. 1, 11)

Female. Color: antenna dull reddish on scape, pedicel, and first 3 or 4 flagellar segments, grading into black on rest of flagellum, except for white above on most of flagellomeres 7-9 and slightly on base of 10; head and mesosoma black with brownish on some margins and sutures and with profuse white markings as follows: large blotch on base of mandible; most of clypeus; very broad orbital ring with ventro-posterior extension across most of malar space and only a brief gap at bottom of eye anteriorly, broad and medially brownish-interrupted band on pronotal collar dorsally; broad band on most of anterio-lateral margin of pronotum; very broad band on dorso-lateral margin of pronotum; most of tegula; broad white stripe along each notaulus on median 0.7 of mesoscutum; most of 
scutellum and postscutellum; most of subalarum; very large oblique blotch on anterior 0.5 of mesepisternum from about upper end of prepectal carina almost to sternaulus at its midlength; small spot in lower hind corner of mesepisternum; dull brown tinged area near top of mesepimeron; very large blotch on most of upper metapleuron; large dorsal area on lower metapleuron along pleural carina on apical 0.6 of sclerite; and lateral 0.3 of propodeum, including crista; gaster red: 1st tergite with a broad white apical band that is briefly interrupted on meson; 2nd tergite with weak dusky staining and a prominent, medially well interrupted subapical white band; 3rd tergite with faint dusky staining but no white; 4th tergite with a very broad, laterally incomplete white apical band; and 5th tergite blackish red with a broad, laterally incomplete white apical band; 6th and 7th tergites similar to 5th but with narrower white bands; 8 th tergite dull reddish; legs red with black anteriorly on fore coxa, dorsoposteriorly on mid coxa, dorso-anteriorly on fore trochanter, on last 2 or 3 fore and mid tarsomeres, on much of hind trochantellus, inconspicuously toward apex above on hind femur, extensively (especially apicad) on hind tibia, and on much of hind tarsus, as well as with white or whitish anteriorly and posteriorly on fore coxa, dorsally on mid coxa, anteriorly on fore and mid trochanters, and on all of 2 nd and most of basal 0.5 of 1 st tarsomere; wings hyaline with faint brownish staining.

Length of fore wing; $6.5 \mathrm{~mm}$. First flagellomere: 4.4 as long as deep at apex. Malar space: 0.9 as long as basal width of mandible. Temple: 0.3 as long as eye in dorsal view, anteriorly rounded off and then steeply, directly receding. Face: with a large and gently raised, rounded median swelling. Hypostomal carina: a weakly elevated flange. Mesoscutum: notauli nearly percurrent, extremely shallow; mesoscutal surface shining with coarse, reticulate wrinkling along notauli, between notauli on apical 0.5 , and exteriorly on lateral lobes, as well as with some duller micro-reticulate areas centrad on lobes. Mesopleuron: speculum swollen, mostly smooth and polished; surface otherwise shining with strong, rather straight to gently sinuate wrinkles radiating extensively from speculum but grading into more puncto-reticulate surface anteriad and ventrad. Wing venation: radial cell 3.7 as long as wide; areolet large, intercubiti only weakly convergent above, 2 nd abscissa of radius 1.0 as long as 1st intercubitus; 2nd recurrent reclivous, straight; disco-cubitus 
broadly angulate, without a ramellus; nervulus antefurcal; upper part of nervellus 3.5 as long as lower. Propodeum: short, high, basal face gently arched and sloping rearward; apical face discrete, vertical, about as long as basal; spiracle 1.9 as long as wide; basal transcarina sharp throughout; apical trans-carina irregular but traceable between cristae; cristae short ligulate, large and strongly projecting; median apical area irregularly suggested; median longitudinal carinae and lateral longitudinal carinae vague; surface shining, coarsely reticulately wrinkled, except with strong but finer puncto-reticulation basad of basal trans-carina. First gastric tergite: postpetiole 2.0 as wide apically as long from spiracle to apex; surface of petiole shining, finely micro-reticulate on basal 0.7 and polished and nearly smooth on apical 0.3 , with only a few small to medium sized, sparse punctures and scattered short setae which only laterally approach the length of their interspaces; flange laterally at base of petiole unusually low, narrow, and rounded in contour. Second gastric tergite: rather silky-shining with delicate micro-reticulation, except on the polished apex, and with abundant, medium sized, prominent but shallow punctures which are separated by $1-3 \times$ their diameters (densest laterad) and which show some areas of even wider separation mesally and basally; punctures emitting short setae that mostly fall short of the length of their interspaces. Ovipositor: sheathed portion 0.36 as long as fore wing; straight, slender, compressed; nodus weakly defined with a broad but shallow notch; dorsal valve with a gentle, direct taper from notch to apex; ventral valve with fine oblique ridges on tip; tip 0.14 as high at notch as long from notch to apex.

MaLe. Unknown.

TyPe Material. Holotype P: PERÚ, La Libertad Province, Simbal, 16-VII-1982, C. Porter, T. O'Neill. Holotype in Florida State Collection of Arthropods.

ReLATIONSHIPS. This species belongs to the same radiation that includes the North and Middle American Chromocryptus as well as C. poecilma, C. huebrichi, C. prosopis, and C. tomsici from Brasil and Argentina. Its nearest relative and probable vicariant is the south Brasilian C. poecilma (Porter 1967: 210-11), which it approaches in mesoscutal and mesopleural sculpture, as well as in many details of coloration. C. teres differs from C. poecilma by having much sparser punctures on the 2 nd gastric tergite and by 
lacking a white blotch in the upper hind corner of the mesopleuron. The sparse 2 nd gastric punctures (separated mostly by $1-3 \times$ their diameters) also separate $C$. teres from other members of its species group (2nd gastric punctures subadjacent to adjacent).

Field Notes. The unique holotype was swept from semishaded undergrowth along a dry river bed at Simbal near Trujillo, Perú. This locality, at the lower extreme of a fertile valley in the north Peruvian Coastal Desert, has a natural vegetation dominated by Prosopis, Acacia, Opuntia, Cereus, and much other Thorn Scrub (Sonoran-Chaqueñan) vegetation.

Specific Name. From the Latin adjective teres, "polished, rounded, elegant."

\section{Chromocryptus huebrichi (Brèthes)}

(Figs. 1, 4, 8, 9)

Agrothereutes Huebrichi Brèthes, 1913. An. Mus. Nac. Hist. Natl. Buenos Aires 24:41. Lectotype $\&$ (labeled by Townes, 1965), no data, (Buenos Aires).

Spilocryptus argentinensis Mallo, 1954. Idia 73-5:30. Nomen nudum.

Chromocryptus planosae, new subspecies, Townes, 1962. Bull. U.S. Natl. Mus. 216(3): 257.

Trachysphyrus planosae huebrichi Townes, 1966. Mem. Amer. Ent. Inst. 8: 72. Trachysphyrus huebrichi Porter, 1967. Mem. Amer. Ent. Inst. 10: 207-10.

Female. Color: antenna black, brownish below toward apex, sometimes with a small white spot below on scape and at base of 1 st flagellomere, a white band above on flagellomeres 6 (in part) or 7 to 10 or base of 11; head and mesosoma black with profuse white markings as follows: about basal 0.5 of mandible; most of clypeus; orbits very broadly, with a narrow interruption at bottom of eye, and behind expanding to cover most of lower temple and malar space, as well as broadened in front so as to cover most of face except for area above clypeus and below antennal sockets; propleuron apicad; broad margin on anterior margin of pronotum, except near apex; broad band on all but median 0.3 of dorsal margin of pronotum; pair of stripes on mesoscutum; tegula; subalarum; large anterio-median blotch, smaller blotch in lower hind corner, and most of hind margin of mesopleuron; scutellum except near apex; upper metapleuron; ellipsoid blotch on apical 0.5 of lower metapleuron; and broad posterio-lateral bar on propodeum extending from crista to hind margin; gaster pale red; 4th gastric tergite with a 


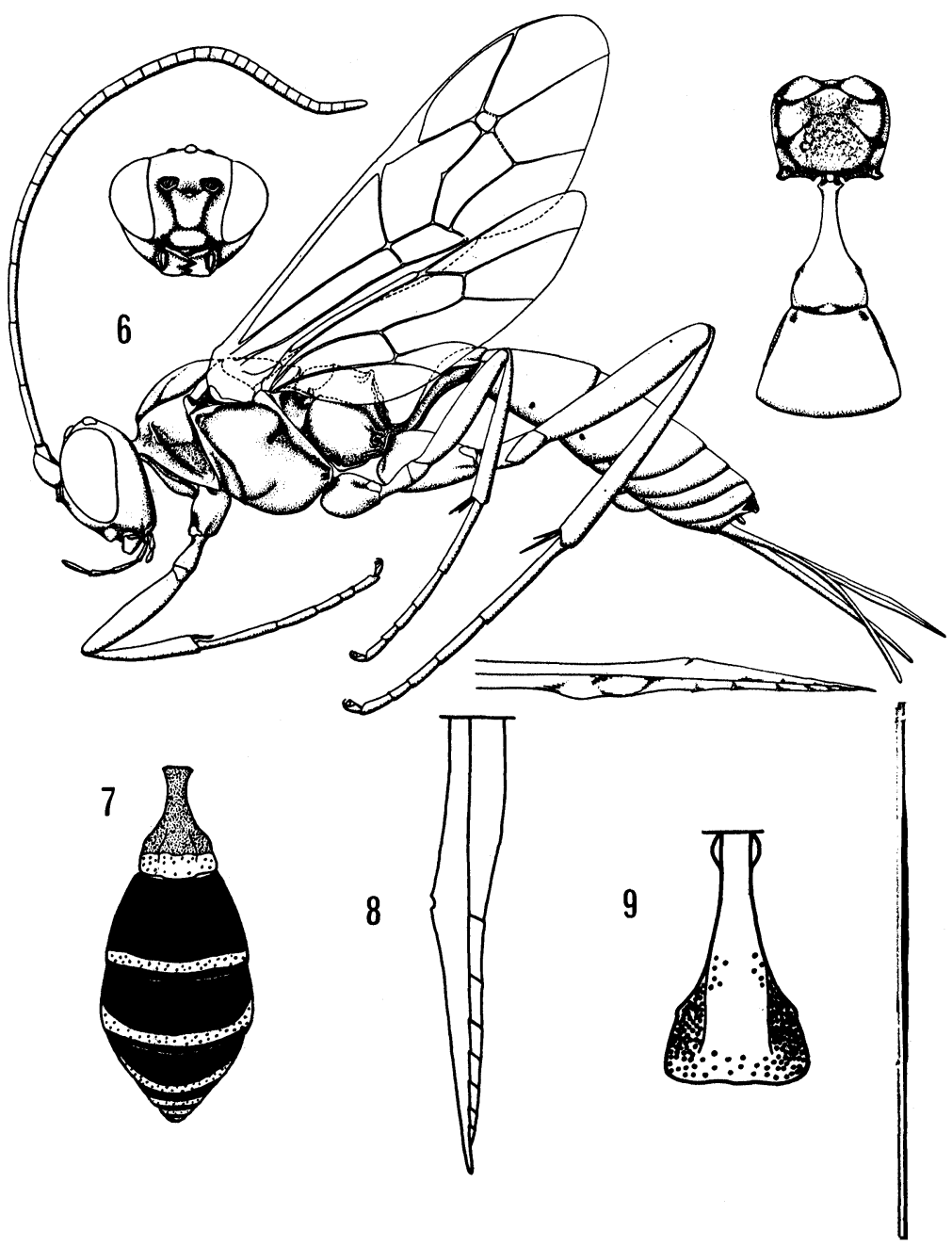

Fig. 6. Chromocryptus planosae, ‥ Habitus sketches of body in lateral view, head in anterior view, and propodeum with first two gastric tergites in dorsal view. (From Townes 1962: 536). Fig. 7. Chromocryptus mesorufus, ․ . Gaster in dorsal view, showing color pattern and habitus. (From Porter 1977: 40). Fig. 8. Chromocryptus huébrichi, . Ovipositor tip in lateral view. (From Porter 1967: Fig. 32). Fig. 9. Chromocryptus huebrichi, ․ Dorsal view of first gastric tergite. (From Porter 1967: Fig. 103). 
white apical band that is preceded by a blackish area; succeeding tergites blackish with dorsally much narrowed white bands; legs pale red: fore and mid coxae and more or less of their trochanters below, white, the trochanters sometimes a little dusky above; hind tibia irregularly dusky toward apex; fore and mid tarsi dusky toward apex; hind tarsus more or less dusky with a usually subapical white band or blotch on 1st segment and with more or less of segments 2-4 white; wings hyaline, sometimes faintly brownish apicad.

Length of fore wing: $5.6-6.7 \mathrm{~mm}$. First flagellomere: $5.3-5.5$ as long as deep at apex. Malar space: $0.9-1.1$ as long as basal width of mandible. Temple: $0.30-0.40$ as long as eye in dorsal view; rounded off and strongly receding. Mesoscutum: notauli narrow and very weak except near base, traceable 0.5-0.7 the length of mesoscutum; surface dully shining, throughout coarsely and granularly punctoreticulate. Mesopleuron: speculum swollen, largely smooth and polished; surface otherwise rather finely puncto-reticulate to reticulately wrinkled. Propodeum: spiracle $1.7-2.0$ as long as wide; basal transcarina well defined throughout, sometimes a little irregular; apical trans-carina weaker than basal, becoming very indistinct medially; cristae large and stout, obtusely cuneate; median apical area irregularly suggested; surface strongly reticulately wrinkled. First gastric tergite: postpetiole $1.7-2.3$ as wide apically as long from spiracle to apex; surface of postpetiole smooth and shining with fine, often largely obscure micro-reticulation and with scattered large, sharp punctures which become mostly subadjacent to adjacent over a broad area laterally and which emit short setae that laterally largely equal or a little exceed the length of their interspaces. Second gastric tergite: smooth and shining with fine, rather obscure microreticulation that becomes stronger laterad and with abundant large, sharp, mostly subadjacent to adjacent punctures that average more crowded and a little smaller toward apex and, especially, laterad, and which emit short setae that mostly equal or exceed the length of their interspaces. Ovipositor: tip $0.17-0.21$ as high at notch as long from notch to apex.

MALE. Differs from female as follows: Color: antenna black except for a large white spot below on scape; clypeus and face almost wholly white; only basal 0.7 of scutellum white; apical 0.5 of 3 rd gastric tergite blackish; 4th tergite more generally blackish, its 
apical white band interrupted medially; succeeding tergites more deeply black than in female, their white apical band broader and not narrowed above; white blotch on clasper; fore and mid trochanters with a brownish stripe above; hind femur slightly dusky near apex; hind tibia dull red, becoming gradually blackish above beyond base, especially on apical 0.5 .

Length of fore wing: $5.1 \mathrm{~mm}$. First flagellomere: 3.6 as long as deep apically. Malar space: 0.7 as long as basal width of mandible. Temple: 0.50 as long as eye in dorsal view; rounded off and moderately receding. Mesoscutum: surface with stronger, larger, and more discrete punctures than in female, which are mostly adjacent to reticulately confluent on central lobe but which on lateral lobes become partly subadjacent with palpable interspaces. Propodeum: spiracle 2.1 as long as wide; basal trans-carina very sharp and high; apical trans-carina a little irregular but strong and sharp; cristae large and strongly projecting short-ligulate; median longitudinal carinae sharp throughout, rather strongly but irregularly defining the median apical area; lateral longitudinal carinae strong and sharp; surface grossly reticulate. First gastric tergite: postpetiole 1.4 as wide apically as long from spiracle to apex; surface of postpetiole smooth and shining with only a trace of micro-reticulation, its punctures even larger and sharper than in female but sparser, mostly subadjacent laterad; setae a little longer than in female but mostly well separated. Second gastric tergite: with punctures that are even larger, sharper, and denser (mostly subadjacent) than in female.

SPECIMENS EXAMINED. $16 \%$ and 10: ARGENTINA, Buenos Aires Province, Olivos, XI-1952, J. Foerster (Ottawa); BRASIL, Paraná State, Quatro Barros nr. Curitiba, 5-II-1966, H. and M. Townes (Townes).

Relationships. Townes (1966: 72) has regarded C. huebrichi as a subspecies of the eastern North American C. planosae. The two entities, indeed, are closely related. They share such features as a delicate and sagittate ovipositor tip, lack of smooth areas on the mesocutum, and absence of strong wrinkles radiating from the mesopleural speculum. However, the following characters distinguish $C$. huebrichi from its Nearctic congener: propodeum and mesopleuron black with white markings (versus extensively red as well as with black and white maculation), face mostly white (versus mostly black), lower metapleuron black with a large white blotch 
(versus mostly red), malar space $0.9-1.1$ as long as basal width of mandible (versus 0.8-0.9), propodeal spiracle $1.7-2.0$ as long as wide (versus 1.4-1.5), and large punctures widely scattered on median field of postpetiole (versus rather dense).

Chromocryptus huebrichi also much resembles the northwest Argentine C. tomsici, C. prosopis, and C. golbachi. These species are distinguished in the key but also show some additional differences, as summarized here: female of C. huebrichi with 1st flagellomere 5.3-5.5 as long as deep at apex (5.8-6.0 in C. tomsici); malar space in female $C$. huebrichi $0.90-1.0$ as long as basal width of mandible (0.84-0.85 in C. tomsici); propodeal spiracle $1.7-2.0$ as long as wide in C. huebrichi (1.3-1.5 in C. prosopis); female postpetiole with scattered punctures medially in $C$. huebrichi (with dense punctures, even on median field, in C. tomsici); no white on male postscutellum in C. huebrichi (postscutellum mostly white in C. golbachi); malar space 0.70 as long as basal width of mandible in $C$. huebrichi males (0.80 in C. tomsici, $0.53-0.66$ in C. prosopis, and $0.80-0.85$ in $C$. golbachi); male postpetiole 1.4 as wide apically as long from spiracle to apex in C. huebrichi (1.2 in C. tomsici, 1.6 in C. prosopis, and 1.8-1.9 $\times$ in C. golbachi); and male postpetiole with large punctures sparse medially in $C$. huebrichi (subadjacent to reticulately confluent in C. prosopis and C. golbachi).

The above-cited differences show that C. huebrichi, C. planosae, C. tomsici, C. prosopis, and C. golbachi manifest multiform but often slight phaenotypic divergence. When more specimens are collected, they should furnish evidence about the extent of geographic and intrapopulation variability among these Chromocryptus and prove whether this widely distributed Planosae group consists mainly of discrete species or of intergrading geographic races.

Habitat Notes. Most of the type series was collected near Curitiba, Brasil on the $1000 \mathrm{~m}$ high, cool, wet Planalto of Paraná State. This region is characterized floristically by subtropical wet forests of myrtaceous and other angiosperm trees plus Araucaria and Podocarpus. The forests are broken in places by grasslands, whose biota recalls that of the Argentine pampas.

I have no information as to the precise microhabitats where $C$. huebrichi was collected.

Hosts. Mallo (1954, as cited above) reared C. huebrichi from the lasiocampid moth, Titya proxima. 


\section{Chromocryptus prosopis Porter, new species}

(Figs. 1, 10)

Female. Color: scape and pedicel brownish black, a large white area below on scape; flagellum dark brown with a reddish tint and with a white band above on flagellomeres 6 (beyond base) to 11 (slightly on base); head black with white as follows: on a broad orbital ring, which may be narrowly interrupted at bottom of eye or complete and below expanded so as to cover most of temple; on a large V-shaped median facial area (contiguous dorso-laterally with white orbital ring), on most of clypeus (contiguous above with the white facial blotch); and on basal 0.5 or more or mandible, as well as with more or less well developed light brown areas in anterior white orbital bands, light brownish on antennal sockets, on apical margin of clypeus, on part of mandible, and sometimes elsewhere; mesosoma dull red with extensive dusky to black staining, especially on pronotum and mesoscutum, as well as with white as follows: spot on apex of propleuron; broad band on anterior margin of pronotum, extending almost to apex; very broad band on all but median 0.3 of dorsal margin of pronotum; tegula; subalarum; basal $0.3-0.6$ of scutellum; most of upper metapleuron; small white area at apex of lower metapleuron; broad posterio-lateral bar on propodeum from crista to hind margin; gaster dull to bright red with some weak but extensive dusky staining and with white as follows: a broad apical band on 1st tergite, a narrower and somewhat fragmented apical band (broader laterad) on 2 nd tergite, and 4 th tergite with a very broad white apical band that ends abruptly laterad far from lower margin; fore and mid coxae and trochanters mostly white with some blackish and reddish areas; legs otherwise reddish, paler on fore legs, and with much dusky on tarsi, as well as with 3rd and (sometimes) most of 4th hind tarsomeres white; wings hyaline with a vague brownish tint apicad.

Length of fore wing: $5.8-6.0 \mathrm{~mm}$. First flagellomere: $5.0-5.6$ as long as deep at apex. Malar space: $0.93-1.0$ as long as basal width of mandible. Temple: $0.36-0.43$ as long as eye in dorsal view; anteriorly rounded-off and then very strongly receding. Mesoscutum: weakly to very weakly traceable for about 0.5 the length of mesoscutum; surface dully shining and uniformly with strong punctoreticulation plus (especially medio-por teriad) coarse reticulate wrinkling. Mesopleuron: speculum swollen, mostly smooth and polished; 


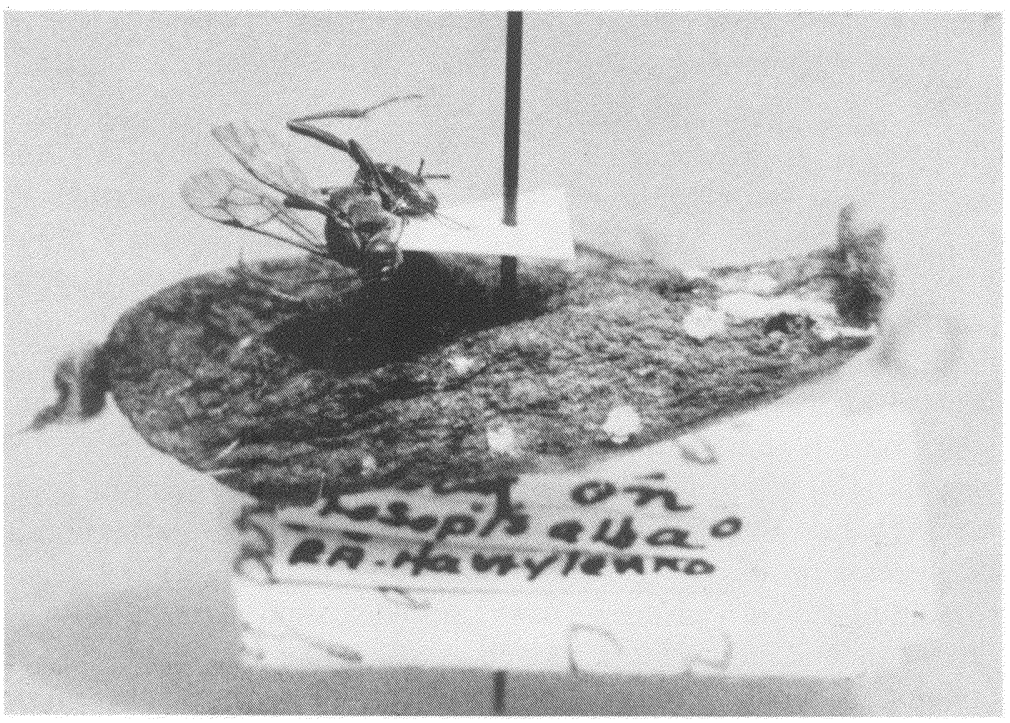

Fig. 10. Chromocryptus prosopis, ‥ Holotype. Photograph of entire insect and cocoon from which it emerged.

surface otherwise uniformly, rather finely and granularly punctoreticulate. Propodeum: spiracle 1.3-1.5 as long as wide; basal transcarina sharp and high throughout; apical trans-carina traceable but weak to obsolete (especially mesad), irregular, its cristae large and stout, cuneo-ligulate, conspicuously projecting; median and lateral longitudinal carinae scarcely suggested, neither the areola nor the median apical area defined; surface largely with strong reticulate wrinkling, but more puncto-reticulate basad of basal trans-carina. First gastric tergite: postpetiole $1.8-2.0$ as wide apically as long from spiracle to apex; surface of postpetiole smooth and silky-shining with faint micro-aciculation and very large, sharp punctures which become mostly subadjacent laterad but are very sparse elsewhere, punctures emitting short setae which even laterad do not surpass the length of their interspaces; base of petiole with a low and roundedoff lateral flange. Second gastric tergite: shining, with a little microreticulation and with abundant, mostly subadjacent to somewhat reticulately confluent, sharp, medium sized punctures; its setae short, mostly equalling or falling a little short of the length of their 
interspaces. Ovipositor: tip $0.18-0.20$ as high at notch as long from notch to apex.

MALE. Differs from female as follows: Color: antenna brownish, more red-tinged below, with white only on scape below; clypeus and face often almost completely pure white; white orbital ring very broad, reaching rearward to occipital carina on lower 0.6 of temple; propleuron largely white; mesopleuron with white irregularly below on prepectus, white on a large blotch in lower front quadrant just distad of prepectal carina, and also white on a broad band that parallels sternaulus below and reaches about 0.6 the distance to apex of mesopleuron; mesepimeron white dorsally; scutellum white on basal 0.7; gaster with a broad white apical band on both 1st and 2nd tergites, a narrower and laterally aborted white apical band on 3rd tergite (or rarely without white on tergite 3 ), and a broad and laterally aborted white apical band on 4th tergite; fore tibia and tarsus tinged with whitish; 3 rd and 4th hind tarsomeres white.

Length of fore wing: $5.3-5.4 \mathrm{~mm}$. First flagellomere: $3.8-4.0$ as long as deep at apex. Malar space: $0.53-0.66$ as long as basal width of mandible. Mesoscutum: notauli narrow but well defined, traceable about 0.8 the length of mesoscutum; surface coarsely punctoreticulate throughout. Propodeum: spiracle 1.7 as long as wide; median longitudinal carinae weakly to rather strongly defined and more or less vaguely delimiting an areola and a median apical area; lateral longitudinal carinae weak and irregular; surface grossly reticulate. First gastric tergite: postpetiole $1.6-1.7$ as wide apically as long from spiracle to apex; surface of postpetiole with numerous large, coarse punctures which may be in great part subadjacent but sometimes are irregularly sparser or even mostly sparse; baso-lateral flange of petiole small and weak. Second gastric tergite: with even coarser, larger, and denser punctures than in female, most of which are adjacent to reticulo-confluent.

Type Material. Holotype \%: ARGentiNA, Santiago del Estero Province, Santiago del Estero, reared from cocoon adhering to bark of Prosopis alba found by D. Havrylenko during VIII-1963. Paratypes: 20 and $5 \hat{\varnothing}$, same data as holotype. Holotype in Florida State Collection of Arthropods. Paratypes in Collection of Charles

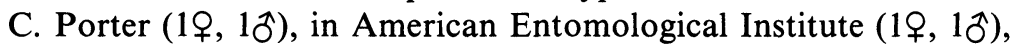
in the Museum of Comparative Zoology (1ठ), in the Snow Entomo- 


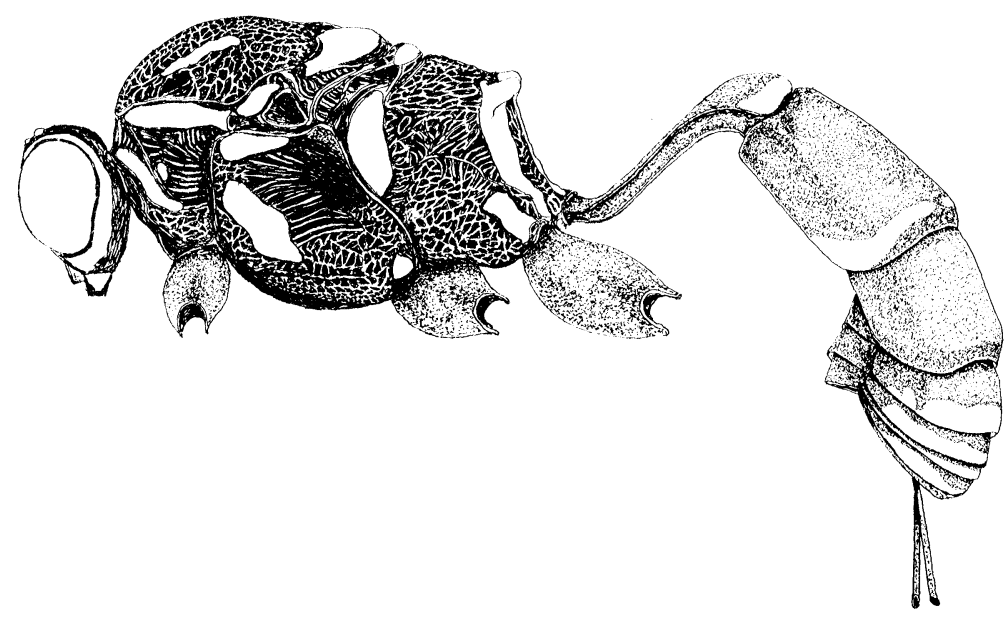

Fig. 11. Chromocryptus teres. $\$$. Holotype. Body in lateral view, showing habitus and color pattern.

logical Museum of the University of Kansas (1 $\hat{\alpha})$, and in the Collection of Texas A\&M University (1ڤ).

Relationships. Chromocryptus prosopis is very similar to the nearly sympatric $C$. tomsici. Besides the diagnostic features cited in the key, C. prosopis has the 1st female flagellomere 5.0-5.6 as long as deep at apex (5.8-6.0 in C. tomsici) and the female malar space $0.93-1.0$ as long as the basal width of the mandible $(0.84-0.85$ in $C$. tomsici).

Field Notes. The type locality is in the Dry Chaco Biome of northern Argentina, a semideciduous subtropical forest and scrub characterized by such plants as Prosopis, Acacia, Cercidium, Schinopsis, Aspidosperma, Celtis, Condalia, Zizyphus, Trithrinax, Opuntia, and many other xerophytes. This community in floristic composition and environmental parameters much resembles the south Texas Thorn Scrub, where Chromocryptus mesorufus has been collected.

Hosts. All of the type specimens were reared from a single, large, tough, gray cocoon found on Prosopis alba (Leguminosae), a South American mesquite. Gregarious parasitism also has been observed in the North American Chromocryptus planosae (Townes 1962: 258). 
Specific Name. For the leguminous shrub, Prosopis, on which the host of this species feeds.

10. Chromocryptus tomsici Porter, new species

(Figs. 1, 12)

Female. Color: scape dark reddish brown with a white area beneath, pedicel and flagellum brown to black with white above on flagellomeres 7-10 or sometimes onto base of 11; head black with white on a broad orbital ring that is briefly interrupted at bottom of eye, on a large, V-shaped median facial mark (in some specimens small and irregular), on most of clypeus, and on much of basal 0.5 of mandible; mesosoma black with white as follows: a broad band (sometimes mesally narrowed) on all but apex of anterior margin of pronotum; a band on all but median 0.3 of dorsal margin of pronotum; tegula on basal 0.6 or more; subalarum; basal 0.3 of scutellum; sometimes a tiny spot in lower hind corner of mesopleuron; most of

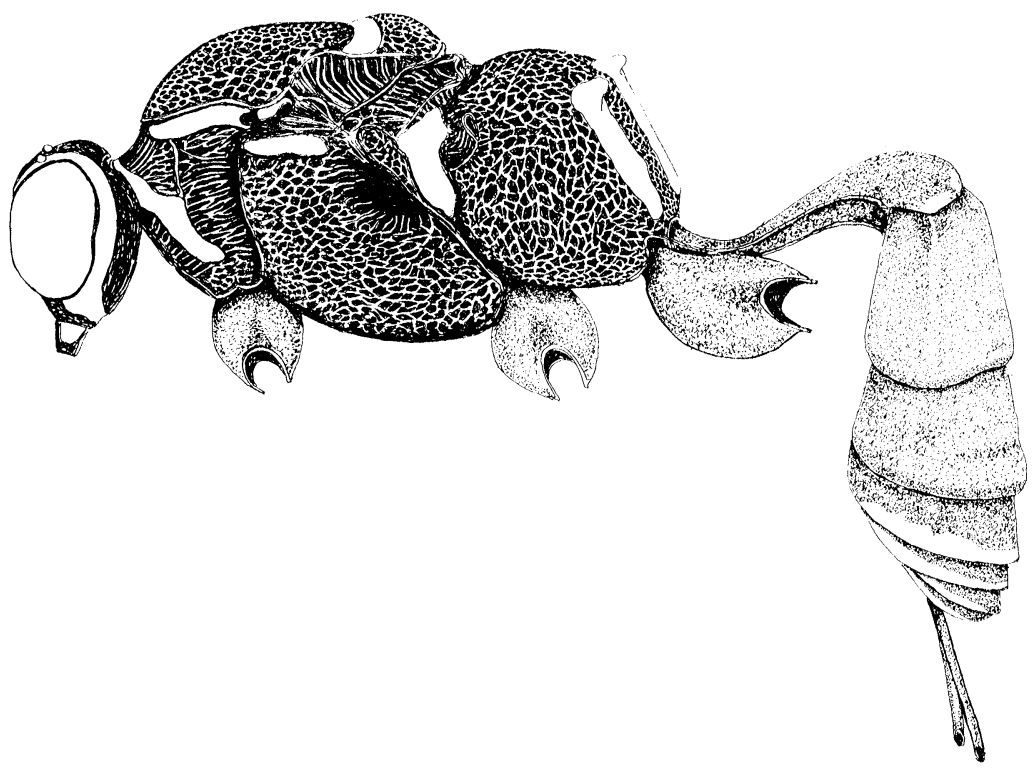

Fig. 12. Chromocryptus tomsici, ㅇ. Holotype. Body in lateral view, showing habitus and color pattern. 
upper metapleuron; sometimes a vague suffusion on apex of lower metapleuron; and broad posterio-lateral bar on propodeum from crista to hind margin; gaster red with some blackish staining, especially on 5th and following tergites but sometimes also extensive on 2nd and 3rd tergites, and with the following white: a broad and medially obsolete apical band on 1st tergite; a very broad and nearly complete apical band on 4th tergite; a narrower, laterally widened apical band on 5th tergite; and with still narrower, dorsad broadly interrupted apical bands on following tergites; fore and mid coxae white with extensive black marks; fore and mid trochanters white below and reddish brown above; legs otherwise red with dusky on tarsi, especially on hind tarsus, and with white on 3rd and (sometimes) also on more than basal 0.5 of 4 th hind tarsomeres; wings hyaline with faint dusky staining apicad on fore wing.

Length of fore wing: $4.6-5.8 \mathrm{~mm}$. First flagellomere: $5.8-6.0$ as long as deep at apex. Malar space: $0.84-0.85$ as long as basal width of mandible. Temple: gently rounded and very strongly receding; $0.37-0.40$ as long as eye in dorsal view. Mesoscutum: notauli very faint, detectable $0.5-0.6$ the length of mesoscutum; surface uniformly with strong rugose wrinkling that sometimes grades into dense puncto-reticulation laterad. Mesopleuron: speculum swollen, mostly smooth and polished, and with a few (sometimes very few) strong and short wrinkles radiating from its periphery; surface otherwise uniformly strongly but rather finely and granularly reticulately wrinkled. Propodeum: spiracle 1.4-1.8 as long as wide; basal trans-carina fine but well developed throughout and sometimes rather strongly raised; apical trans-carina weakly and irregularly traceable throughout; cristae strongly projecting, symmetric, shortligulate or subligulate; longitudinal carinae obsolete; median apical area sometimes irregularly delimited. First gastric tergite: postpetiole 1.8-1.9 as wide apically as long from spiracle to apex; surface of postpetiole silky-shining with at least a little and sometimes with conspicuous micro-reticulation and with abundant very large and coarse punctures that are irregularly distributed but extensively subadjacent on median field and which become even denser laterad; setae rather long, in part equalling the length of their interspaces; base of petiole with a low and subtriangular lateral flange. Second gastric tergite: a little dully shining and minutely aciculate, with abundant, uniformly distributed, medium sized, mostly almost sub- 


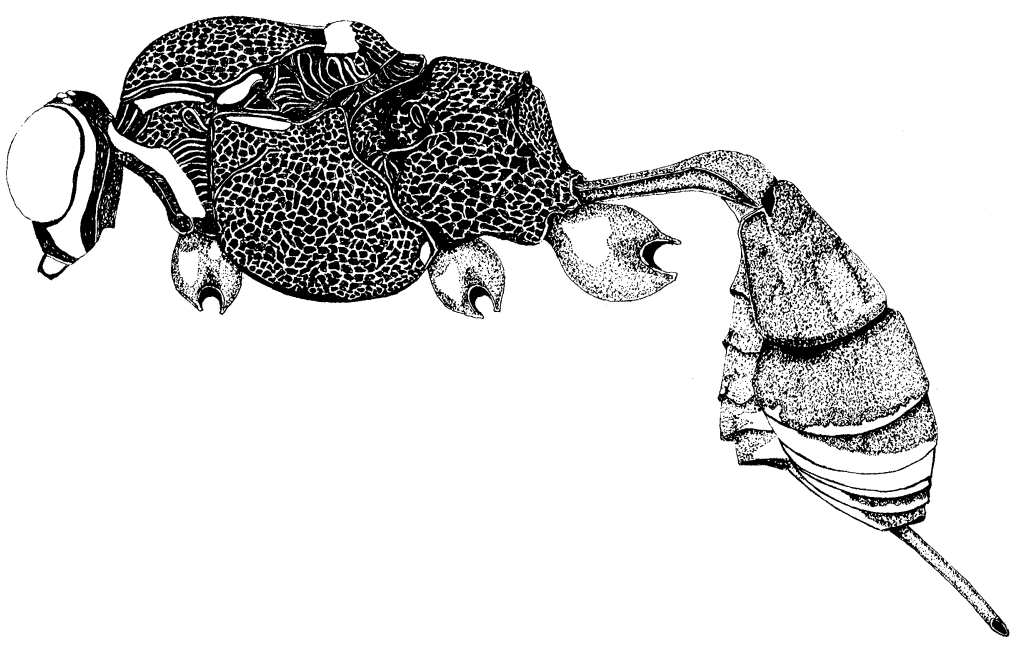

Fig. 13. Chromocryptus alvaradoi, ㅇ. Holotype. Body in lateral view, showing habitus and color pattern.

adjacent to in part reticulately confluent punctures; setae short, mostly about as long as their interspaces. Ovipositor: $0.19-0.21$ as high at notch as long from notch to apex.

MALE. Differs from female as follows: Color: no white on flagellum; face largely white, except for an extensive black spot that reaches dorsad from each anterior tentorial pit and for a median dot below antennal sockets; white spot on apex of propleuron; white on most of basal 0.5 of scutellum; propodeal posterio-lateral white bars broader than in female, leaving only median 0.3 of hind propodeal face black; white vaguely developed on apex of 1st gastric tergite; 4 th tergite with a broad white apical band on median 0.5 only; 5 th and following tergites with broad and complete white apical bands; 3rd and almost all of 4th hind tarsomere white.

Length of fore wing: $5.3 \mathrm{~mm}$. First flagellomere: 4.0 as long as deep at apex. Malar space: 0.80 as long as basal width of mandible. Temple: 0.44 as long as eye in dorsal view. Mesoscutum: notauli fine but definitely impressed, rather sharp, reaching about 0.7 the length of mesoscutum; surface coarsely and uniformly reticulo-punctate. Mesopleuron: surface more definitely reticulo-punctate than in female. Propodeum: spiracle 1.7 as long as wide; basal trans-carina 


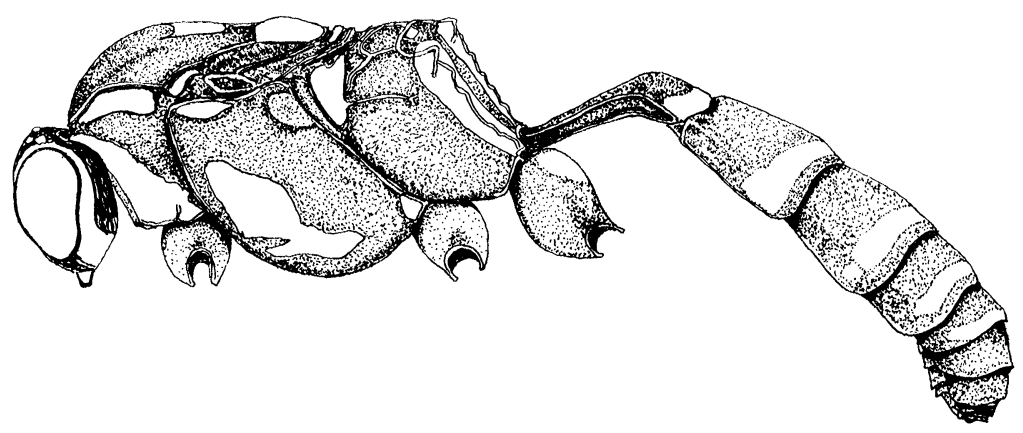

Fig. 14. Chromocryptus golbachi, $\widehat{\jmath}$. Holotype. Body in lateral view, showing habitus and color pattern.

very sharp and high; apical trans-carina strong but irregular; cristae short-cuneate, very large and strongly projecting; median longitudinal carinae irregular but well developed, areola and median apical area defined; surface, especially on apical face, very coarsely reticulately wrinkled. First gastric tergite: postpetiole 1.2 as wide apically as long from spiracle to apex; surface of postpetiole almost uniformly with large and strong, subadjacent to a little reticulately confluent punctures; setae equal or exceed the length of their interspaces; basal expansion of petiole a low and rounded flange.

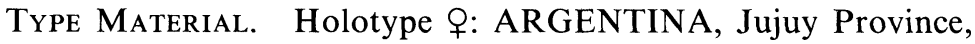
Posta de Lozano, 21-III-1969, C. Porter. Paratypes: 19 and 1 $\widehat{\delta}$, ARgentina, Jujuy Province, Huacalera, 2800 m, 25-III-1969, C. Porter. Holotype in Florida State Collection of Arthropods. Paratypes in Collection of Charles C. Porter.

Relationships. This species shows close affinity to the Argentine C. prosopis and to other members of the Planosae complex within Chromocryptus. Its diagnostic features are summarized in the key and in the discussions of C. tomsici and C. hübrichi.

Field Notes. Chromocryptus tomsici seems to replace the lowland Chaco C. prosopis in the mountains of northwest Argentina. The habitat of the type female, a complex ecotone at $1600 \mathrm{~m}$, already has been discussed under the treatment of $C$. alvaradoi. Huacalera, where the paratypes of $C$. tomsici were collected, is much drier and colder than Posta de Lozano. It belongs to the Prepuna Biome, a high Andean desert characterized by such xerophilous shrubs as Schinus, Prosopis, Acacia, and Cercidium, as well 
as by arborescent cacti of the genus Trichocereus. Most of my ichneumonids from Huacalera were swept from tall bunch grass along an irrigation ditch near the Hotel Monterrey.

SPecific Name. For Professor Zlatko Tomsic of the Universidad Nacional de Tucumán, an unfailing and generous friend during my 23 years of aquaintance with the Argentine Republic.

\section{Chromocryptus golbachi Porter, new species}

$$
\text { (Figs. 1, 14) }
$$

Female. Unknown.

MALE. Color: antenna reddish brown with white on most of scape below; head black with white on a very broad orbital ring (briefly interrupted at bottom of eye), on most of face, on clypeus, and on about basal 0.8 of mandible; mesosoma bright red with blackish extensively in middle of pronotal collar and laterad to or distal of epomia, as well as on some margins and sutures, and with white as follows: on apex of propleuron; very broad band (greatly expanded ventro-laterally) on anterior margin of pronotum; very broad band on all but median 0.3 of dorsal margin of pronotum; a large blotch on mesoscutum between ends of notauli; tegula; subalarum; almost whole scutellum; most of postscutellum; much of ventro-anterior quadrant of mesopleuron distad of prepectal carina; broad and sinuate band following sternaulus from prepectal carina about 0.6 the distance back to hind margin of mesopleuron; small blotch in lower hind corner of mesopleuron; mesepimeron above speculum; all of upper metapleuron; small to large and elongate dorso-apical area on lower metapleuron; very broad, reddishtinged, ventrally widened lateral bar on propodeum from crista to hind margin; and sometimes incomplete hind margin of apical trans-carina of propodeum; gaster bright red with broad and complete white apical bands on tergites 1 and 2, as well as with equally broad but laterally abbreviated white apical bands on tergites 3-5; fore and mid coxae and trochanters white and often variegated with pale red, especially on coxae; fore and mid trochantelli reddish above and white below; hind coxa red with white on most of dorsobasal 0.5 ; hind tarsomeres 3 and (sometimes also) 4 white; legs otherwise red, tending to whitish on fore and mid femora, tibiae, and tarsomeres 1-4, dusky on fore and mid 5th tarsomeres; red of hind leg darker and hind tarsus dusky on segments $1-2$ and 5 and white on segments $3-4$; wings hyaline. 
Length of fore wing: $3.4-4.4 \mathrm{~mm}$. First flagellomere: $3.7-4.0$ as long as deep at apex. Malar space: $0.80-0.85$ as long as basal width of mandible. Temple: $0.36-0.51$ as long as eye in dorsal view; rounded-off and strongly receding. Mesoscutum: notauli fine but definitely impressed, reaching $0.7-0.8$ the length of mesoscutum; surface shining, sometimes almost uniformly with coarse reticulate wrinkling and sometimes with brief smooth interspaces between many of the punctures, especially on lateral lobes. Mesopleuron: speculum smooth, polished, and swollen, peripherally with some coarse irregularly to sometimes rather regularly radiating wrinkles; surface otherwise on upper 0.5 complexly and moderately finely reticulately wrinkled (the wrinkling with some longitudinal bias) but on lower 0.5 becoming regularly puncto-reticulate. Propodeum: spiracle 1.3-1.7 as long as wide; basal trans-carina sharp and high; apical trans-carina strong and complete, more or less irregular; cristae moderately projecting subligulate to ligulo-cuneate; median longitudinal carinae traceable but irregular, defining a very broad and narrow areola and the usual median apical area; surface, especially on hind face, very coarsely and vermiculately reticulately wrinkled. First gastric tergite: postpetiole $1.8-1.9$ as wide apically as long from spiracle to apex; surface of postpetiole silky-shining with conspicuous delicate aciculation and with very large and sharp punctures of somewhat irregular distribution but in great part subadjacent to reticulately confluent; setae short and not or barely attaining the length of their interspaces; base of petiole with a rather strong and rounded lateral flange. Second gastric tergite: dully shining with widespread fine aciculation and abundant, uniformly distributed large and strong, subadjacent to a little reticulately confluent punctures; setae short, mostly equalling the length of their interspaces.

Type Material. Holotype $9:$ ARGENTINA, Santiago del Estero Province, Los Tigres, in Malaise Trap, R. Golbach. Paratype: $1 \hat{\sigma}$, same locality as holotype. Holotype in Florida State Collection of Arthropods; paratype in Collection of Charles C. Porter.

Relationships. This distinctive and brightly colored Chromocryptus belongs to the same complex as C. huebrichi, C. prosopis, and C. tomsici. Most of its diagnostic characters are expounded in the key. Some other features of possible taxonomic importance are 
its malar space length ( $0.80-0.85$ as long as basal width of mandible, versus $0.53-0.66$ as long in c. prosopis, 0.70 in C. huebrichi, and 0.80 in C. tomsici), as well as the presence of some short but strong wrinkles radiating from the specular periphery (such wrinkles are absent in $C$. huebrichi and $C$. prosopis and variably defined in $C$. tomsici).

Field Notes. Los Tigres, in Santiago del Estero Province of the Argentine Dry Chaco Biome, suffers an unusually drastic subtropical semihumid climatic regimen, with long, rainless winters and only sporadically pluvial summers that register thermic maxima of $45-50^{\circ} \mathrm{C}$. The ichneumonid fauna of such localities often is large but rarely becomes accessible for capture by hand net. Thus it is not surprising that the types series of C. golbachi was collected at Los Tigres in the course of a Malaise Trap survey.

Specific Name. For Professor Rodolfo Golbach of the Fundación Miguel Lillo at the Universidad Nacional de Tucumán, who collected the type series and who has done more than any other researcher to document the Argentine entomofauna.

\section{ACKNOWLEDGMENTS}

This research was done under my current National Science Foundation Grant (BSR-8313444) and in part supported by previous grants from the same agency (DEB-75-22426, GB-6925). Grants for field studies in Latin America awarded in 1973, '74, '75, '79, and '81 by the Committee for Research and Exploration of the National Geographic Society helped substantially in amassing specimens and ecological data for Chromocryptus. Additional support was provided by Faculty Fellowships from Fordham University awarded during the Spring Semester of 1980 and the Fall Term of 1984.

As a Research Associate of the Florida State Department of Agriculture and Consumer Services, I have received generous support from the Division of Plant Industry at Gainesville, among whose personnel special thanks befit Dr. Howard V. Weems, Jr., Dr. Lionel A. Stange, and Mr. Harold A. Denmark.

My collecting in the Lower Río Grande Valley of Texas has been facilitated by annual permits issued under authority of the Texas Parks and Wildlife Department. 


\section{SUMMARY}

The mesostenine genus Chromocryptus comprises trachysphyroid ichneumonids with pyramidal clypeus; strongly sculptured mesoscutum; axillus near hind margin of wing; 1st gastric tergite with a palpable basolateral expansion; 2nd gastric tergite with large, dense punctures; and with a short, straight, compressed ovipositor. There are 11 species: Chromocryptus planosae (Fitch) in the northeastern United States; $C$. weemsi (Porter) in Florida; $C$. mesorufus Cushman in Florida, Texas, and México; C. vandykei Townes in California; C. teres n. sp. in Perú's Coastal Desert; C. alvaradoi n. sp., C. golbachi n. sp., C. prosopis n. sp., and C. tomsici n. sp. in northwest and north-central Argentina; $C$. huebrichi (Brèthes) in south Brasil and adjacent Argentina; and C. poecilma (Porter) from Minas Gerais, Brasil. Biomes inhabited by different species of Chromocryptus include Temperate Deciduous Forest, Tropical Wet Forest, Subtropical Cloud Forest, lowland Subtropical Thorn Scrub, and high Andean Desert. Several Chromocryptus have been reared as apparently polyembryonic parasites from moth cocoons (mostly Lasiocampidae) attached to bark.

Much of the material on which this revision is based was collected in northern Argentina during frequent periods of collaboration with the Fundación Miguel Lillo and the Facultad de Ciencias Naturales of the Universidad Nacional de Tucumán. I am particularly grateful to Professor Rodolfo Golbach and to Dr. Abraham Willink of these institutions.

Finally, I thank Mr. Thomas J. O'Neill of Fordham University for his consummate skill in preparing many of the illustrations for this article and for his assistance on several South American fieldtrips.

\section{Literature Cited}

CARLSON, R. W.

1979. Ichneumonidae In Catalog of Hymenoptera in America North of Mexico, Volume 1, Symphyta and Apocrita (Parasitica): 1-1198. Smithsonian Institution Press, Washington, DC. 
PORTER, C.

1967. A revision of the South American species of Trachysphyrus. Mem. Amer. Ent. Inst. 10: 1-386.

1974. A new Trachysphyrus of the Planosae group from Florida. Fla. Ent. 57(3): 331-5.

1977. Ecology, zoogeography, and taxonomy of the Lower Río Grande Valley Mesostenines. Psyche 84(1): 28-91.

Pratt, H. D.

1945. Taxonomic studies of the Nearctic Cryptini. Amer. Midl. Nat. 34: $549-661$.

TOWNES, H. K.

1962. Ichneumon-flies of America north of México: 3. Subfamily Gelinae, Tribe Mesostenini. Bull. U. S. Natl. Mus. 216(3): 1-602.

1966. A catalog and reclassification of the Neotropic Ichneumonidae. Mem. Amer. Ent. Inst. 11: 1-367.

1969. Genera of Ichneumonidae, Part 2: Gelinae. Mem. Amer. Ent. Inst. 12: $1-537$. 

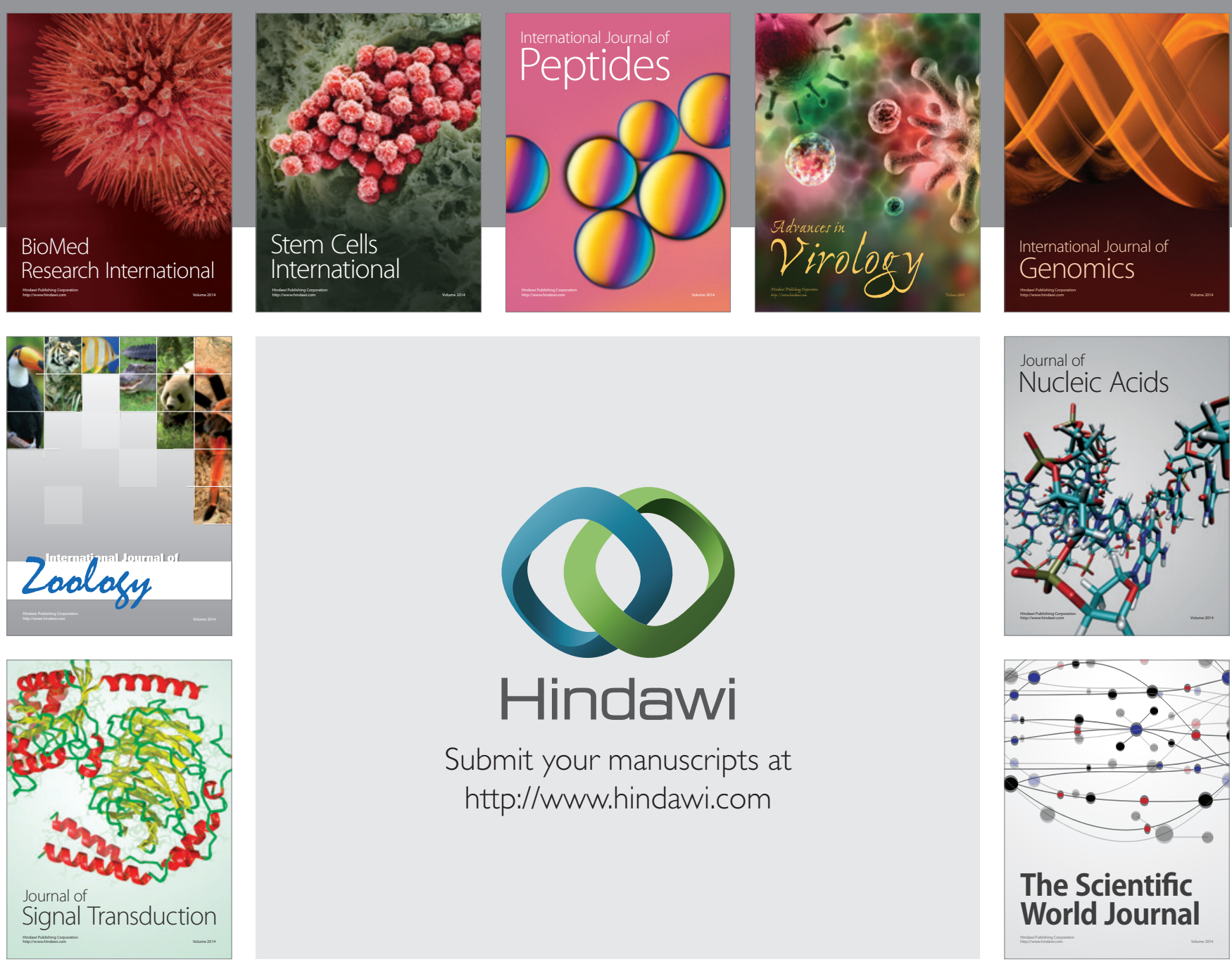

Submit your manuscripts at

http://www.hindawi.com
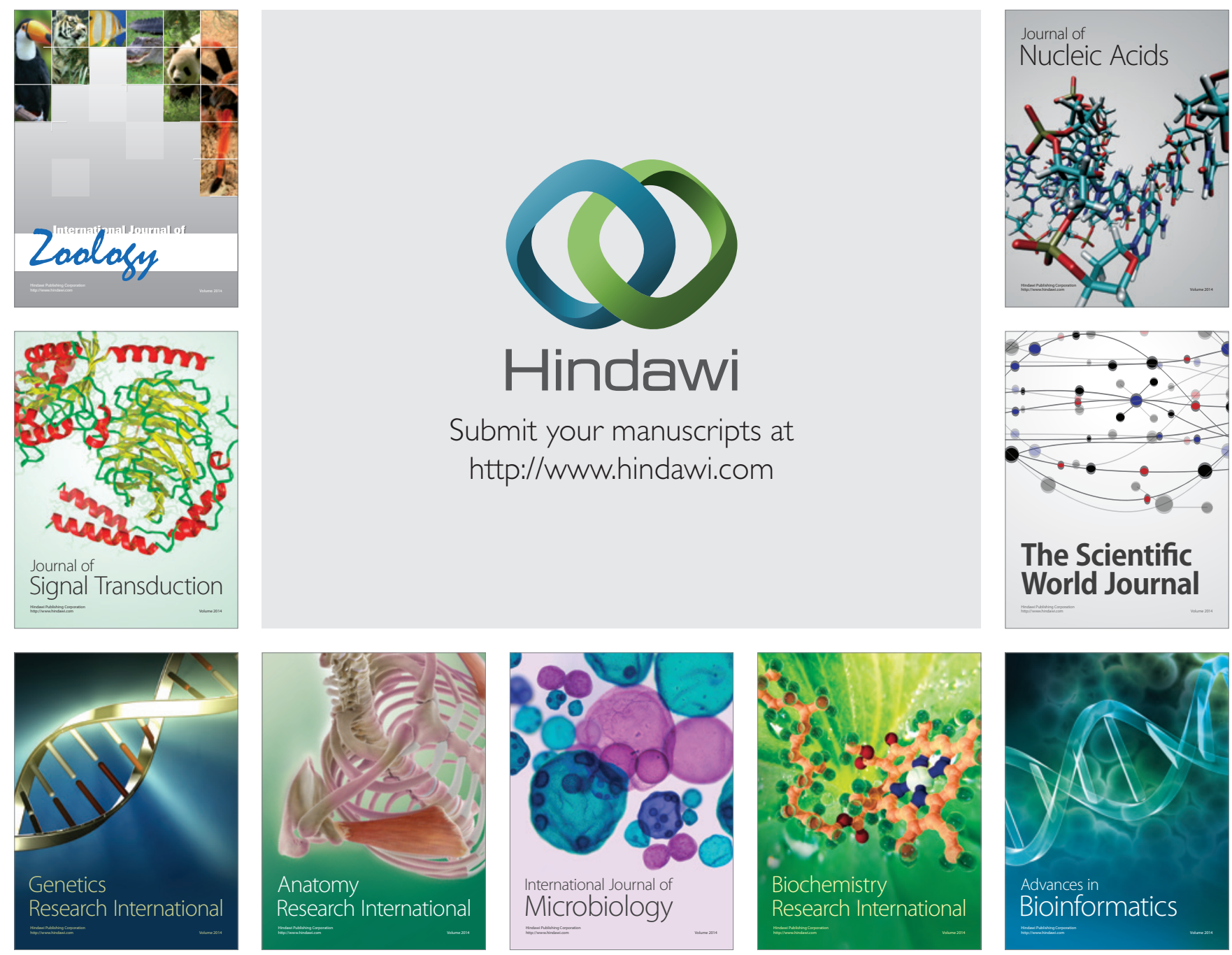

The Scientific World Journal
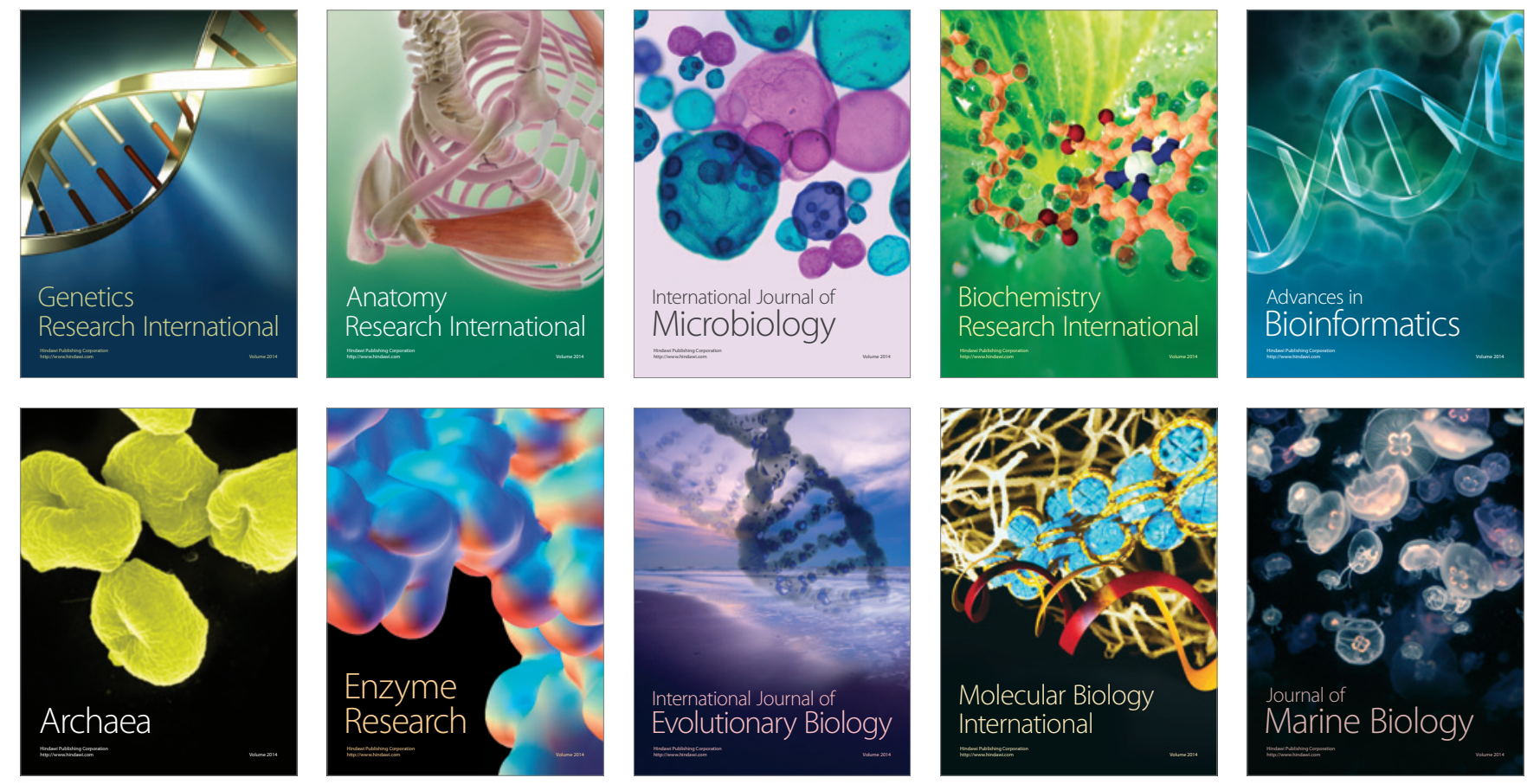